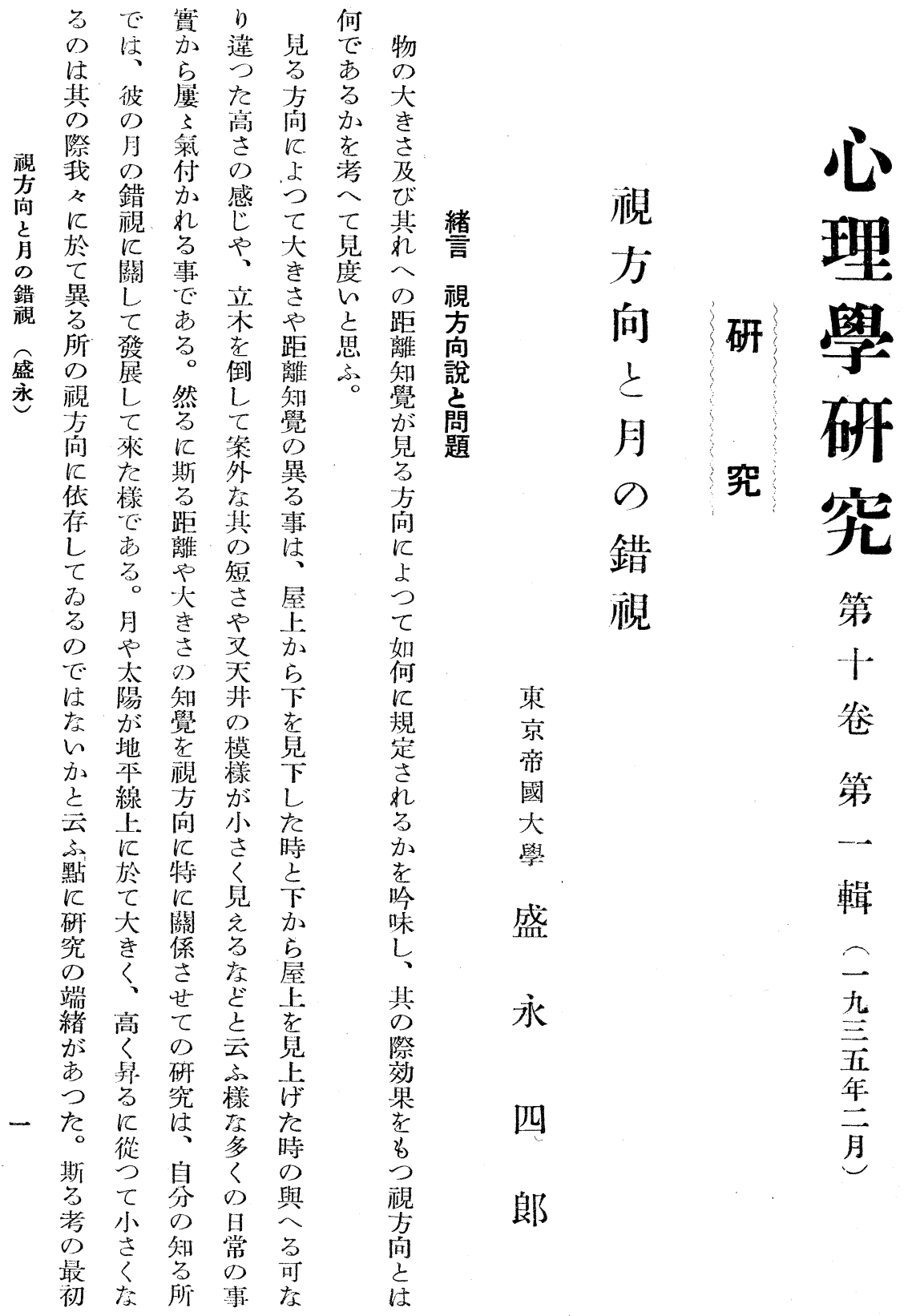




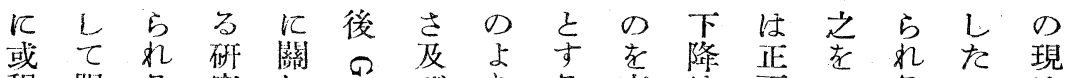

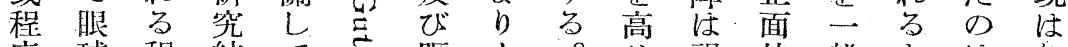
度球程結て臣距名。め視的般吕はれ

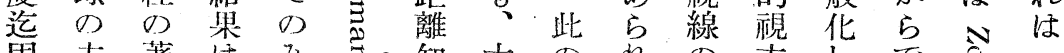

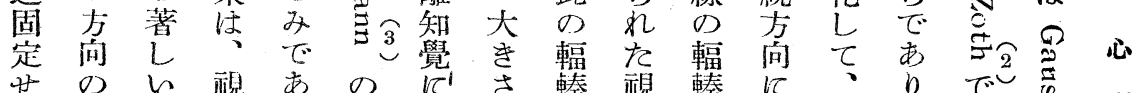
せ め

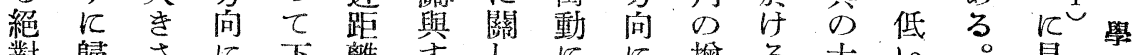

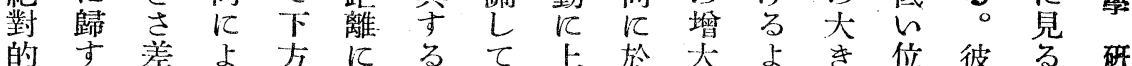
空る異つ向於視は述て在りさ置は事

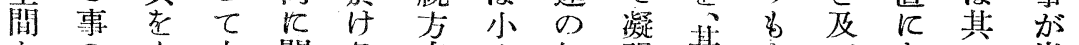

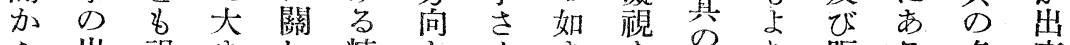

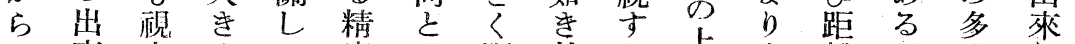

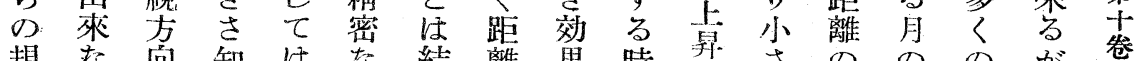

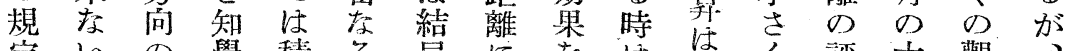

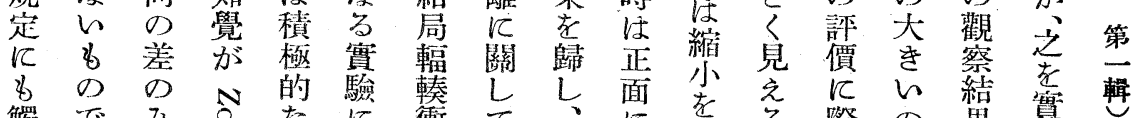
觸で み

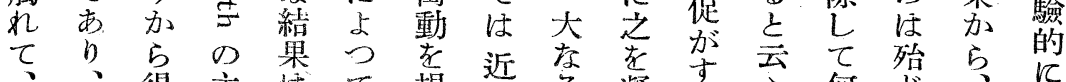

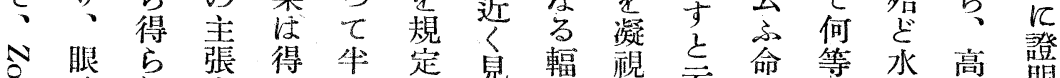

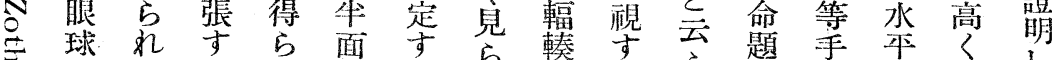

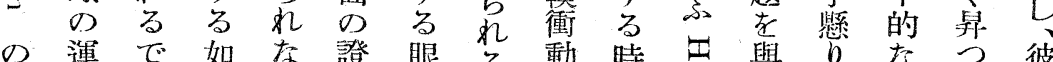

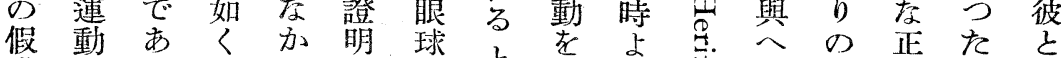

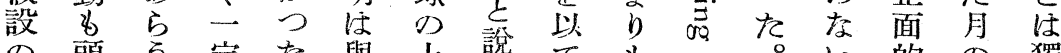
の頭 5 定た 與上說て

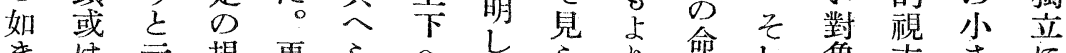

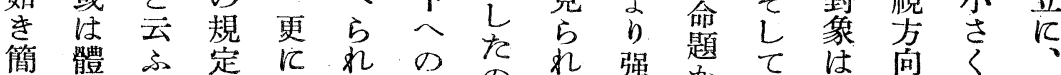

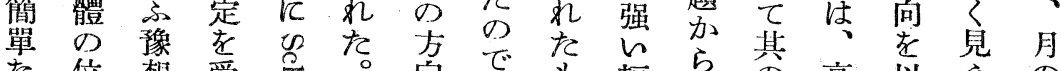

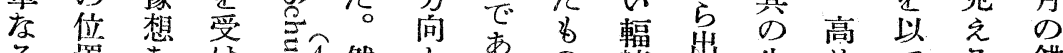

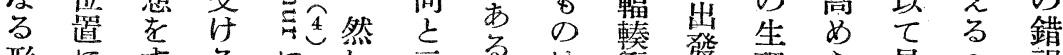

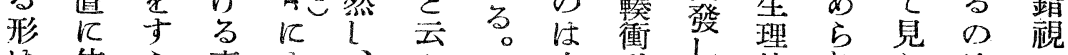

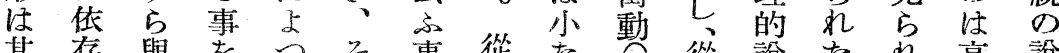

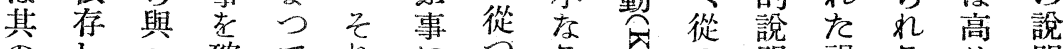

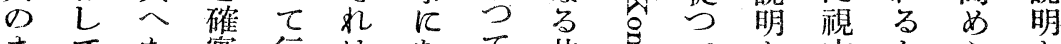

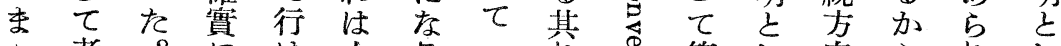
考。注水方 $\mathrm{N}$ 等

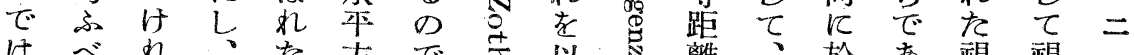

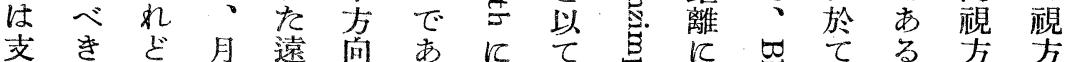

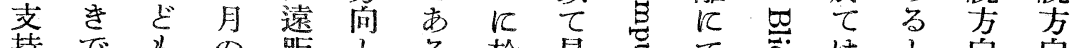
持で

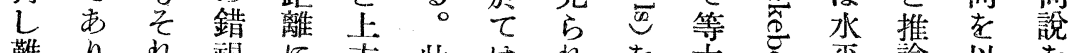

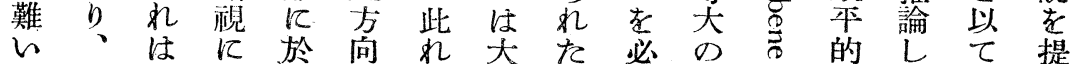

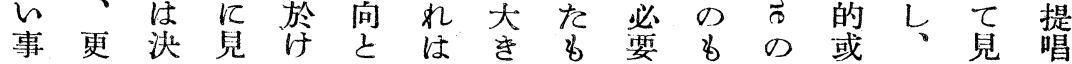




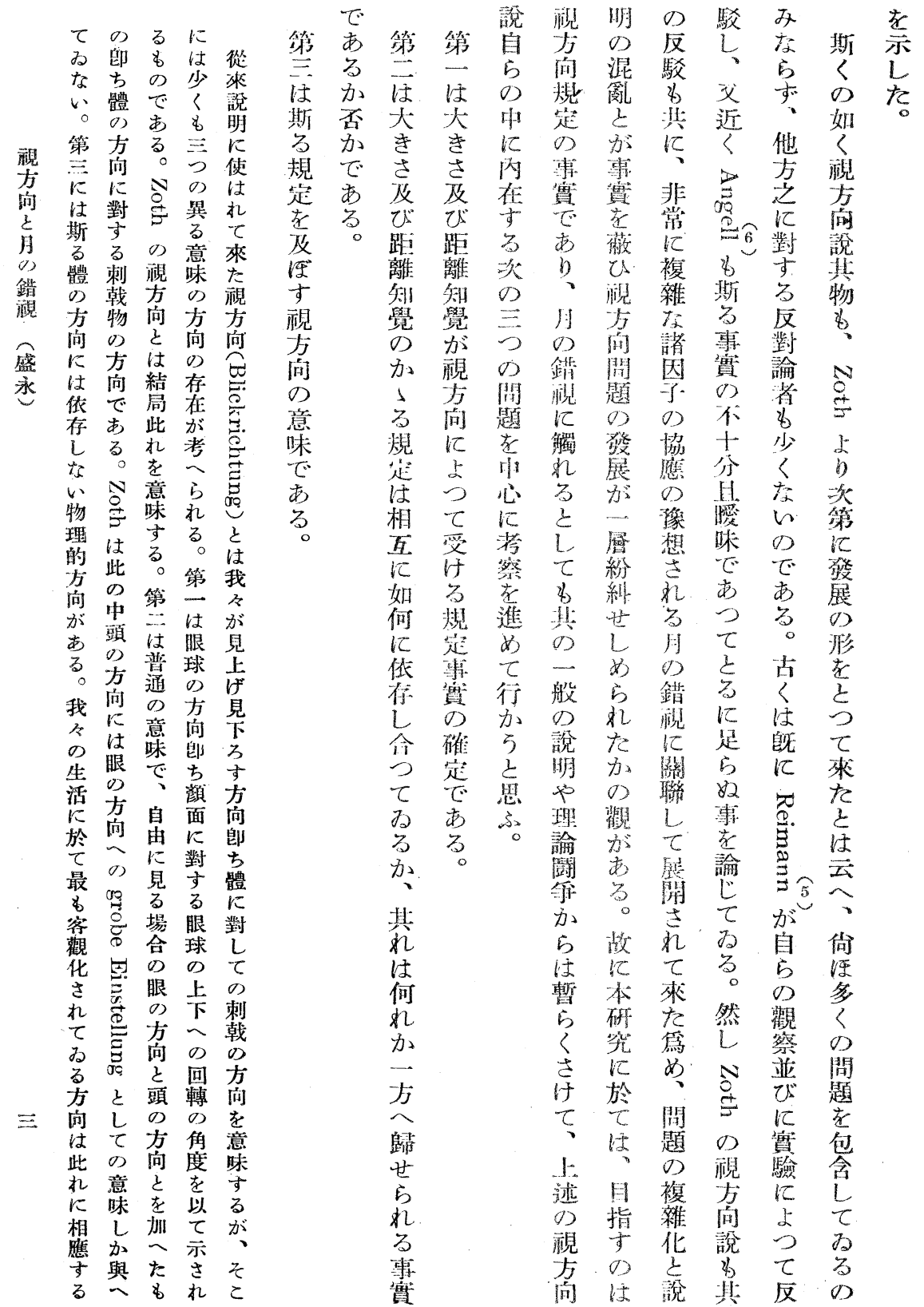




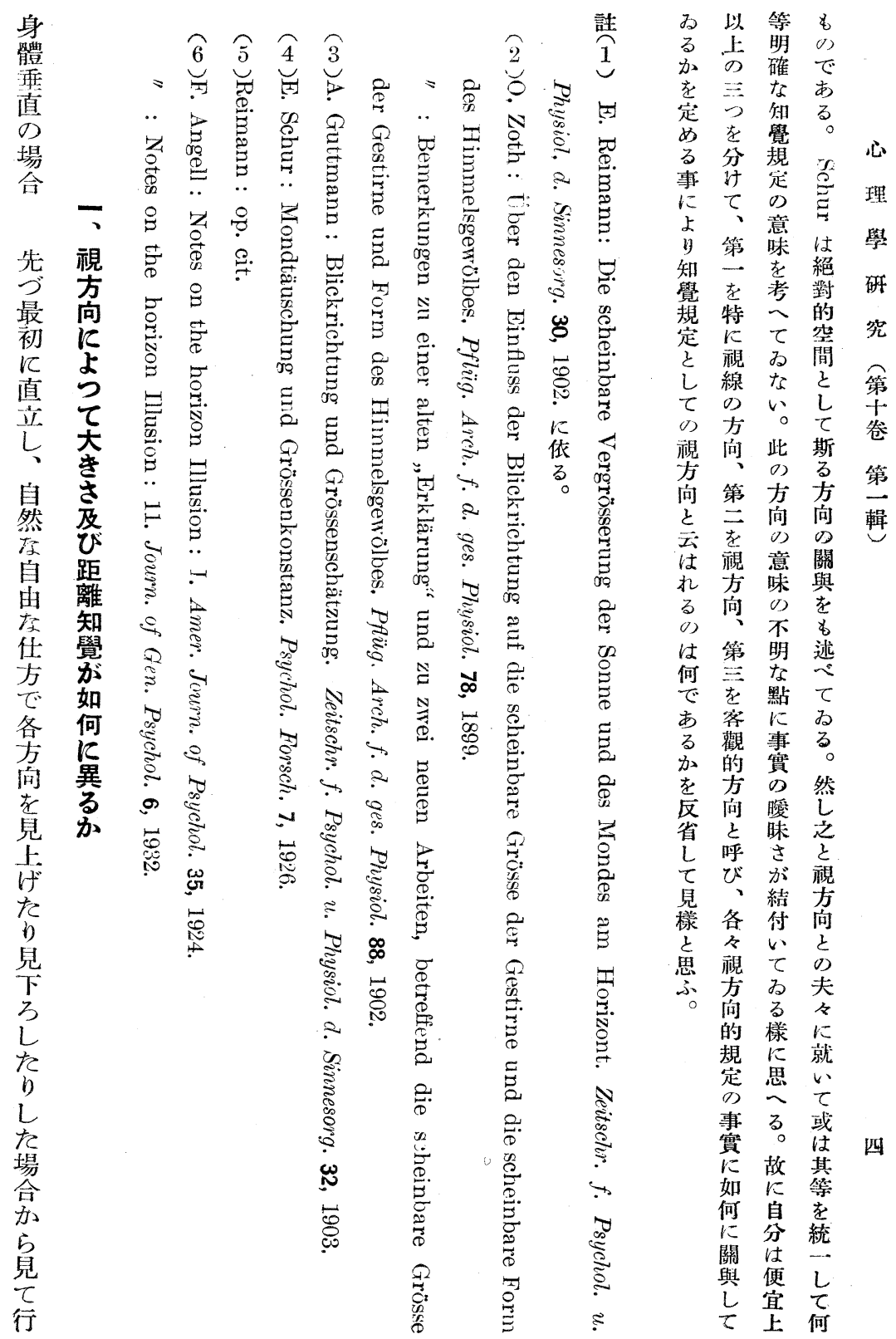




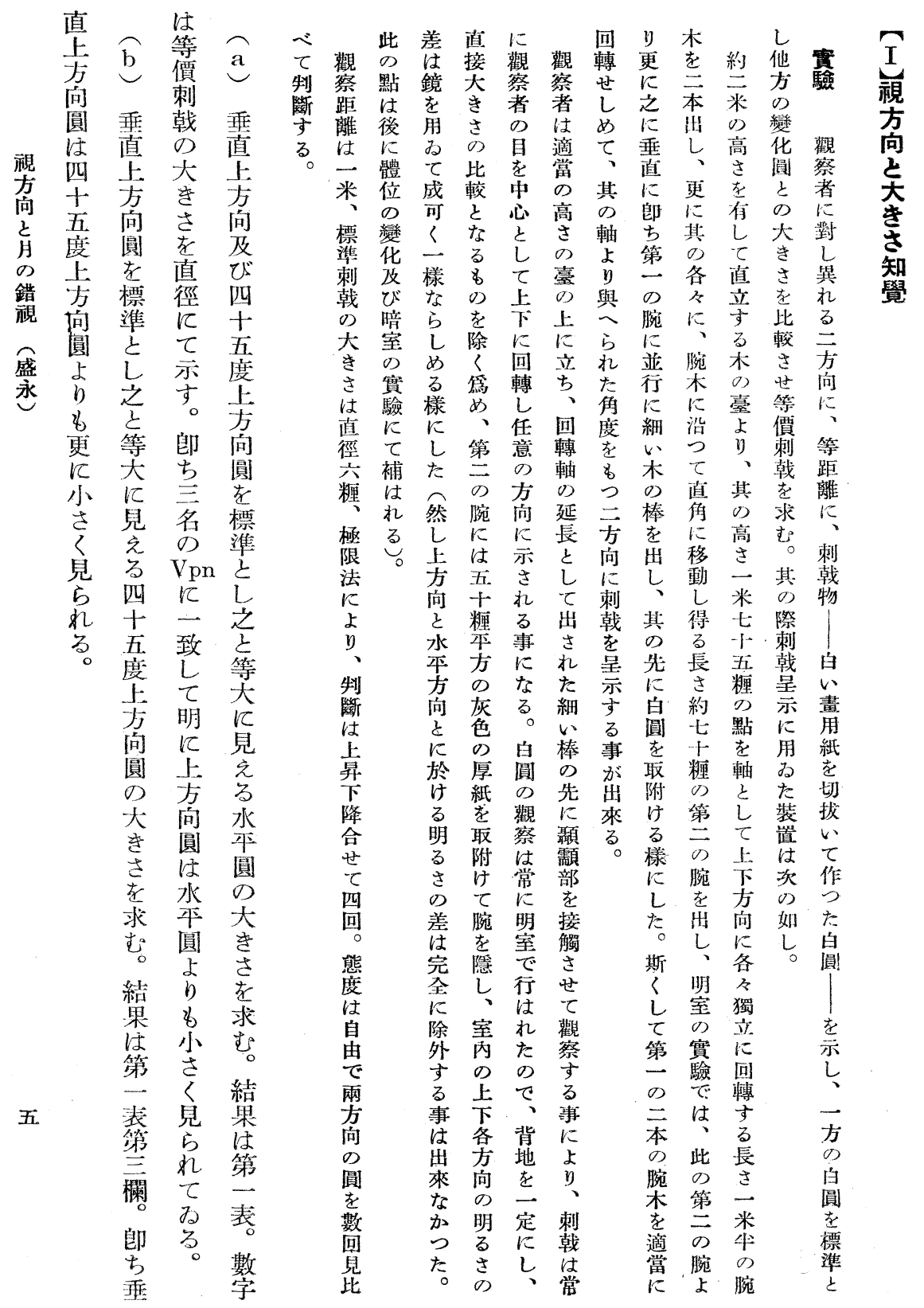




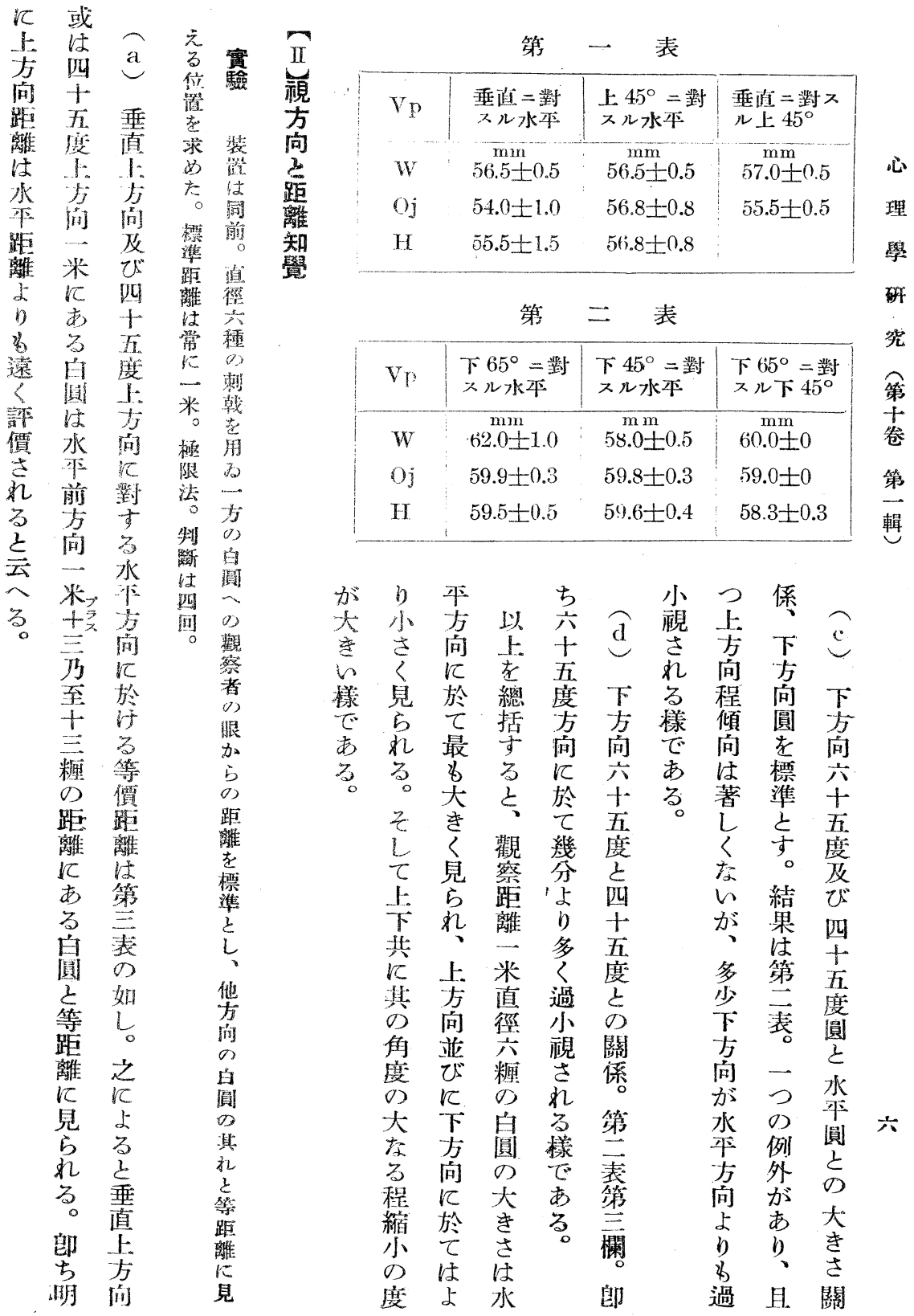




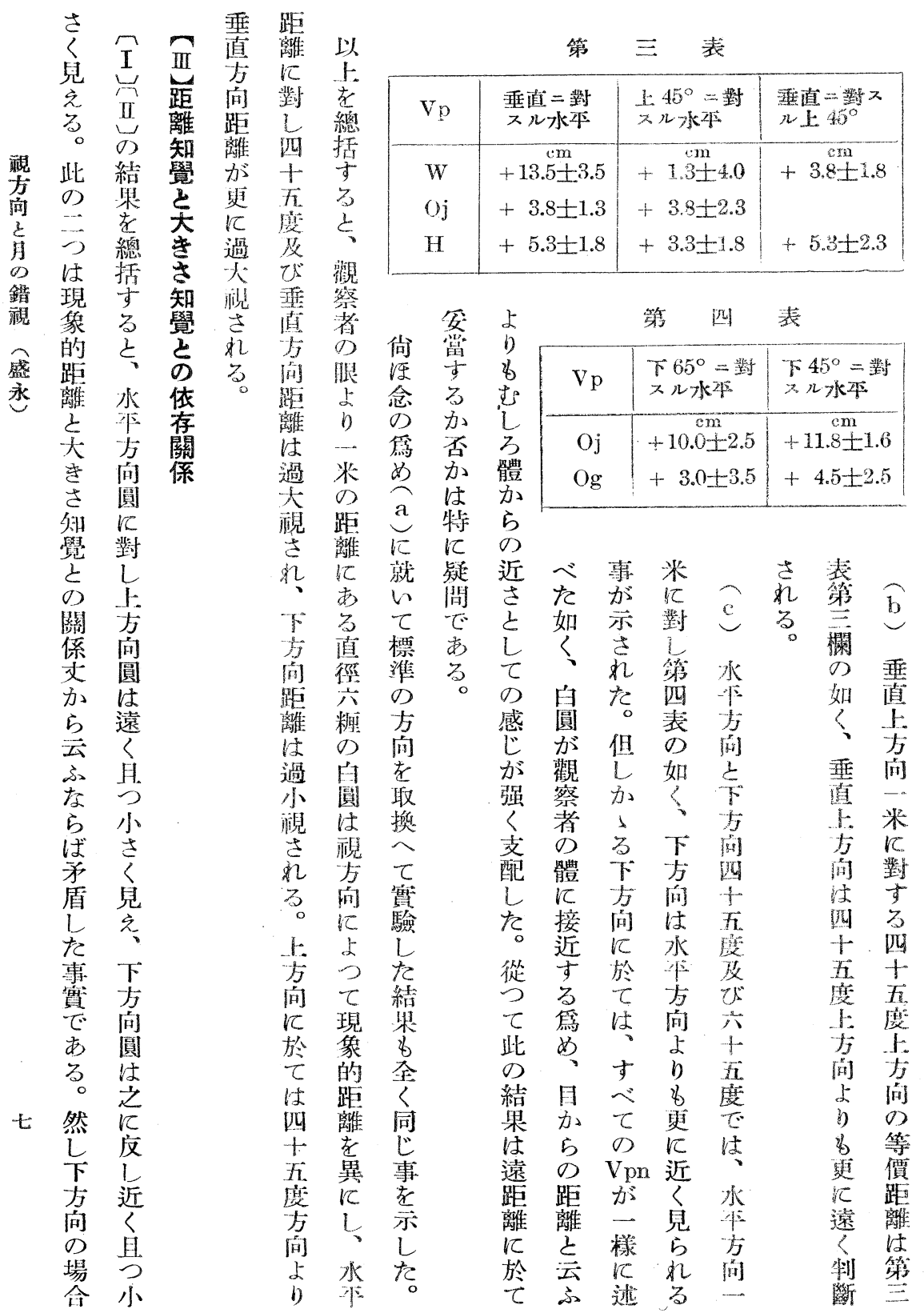


第 五 表

\begin{tabular}{|c|c|c|c|}
\hline $\mathrm{Vp}$ & 水本距離70 & $105 \mathrm{~cm}$ & $130 \mathrm{~cm}$ \\
\hline $\mathrm{Oj}$ & $54.0 \pm 0$ & $56.0 \pm 0$ & $06.0 \pm 0$ \\
$\mathrm{~W}$ & $57.5 \pm 0.5$ & $57.5 \pm 0.5$ & $58.5 \pm 0.5$ \\
\hline
\end{tabular}

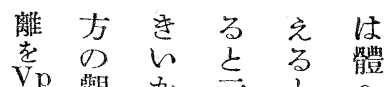
$\mathrm{Vp}$ 觀加云之方

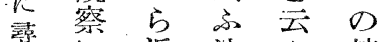
数尔近法主接 た於く則事近 がて 感性自立心 全常艺起身去理 氯他小元既交理

れ之見に其變近之姇方さしし普少

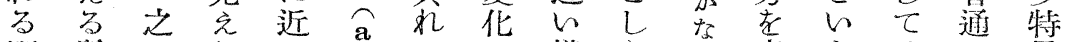

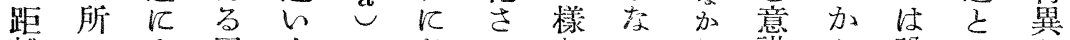

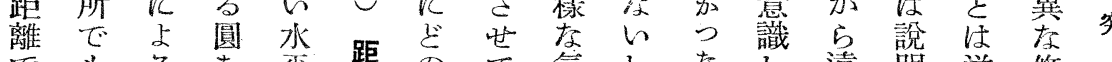

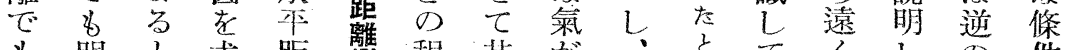
b 明と求距變程其方・会てくしの件

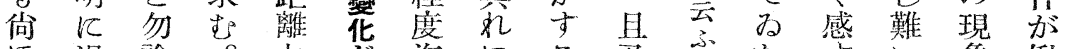

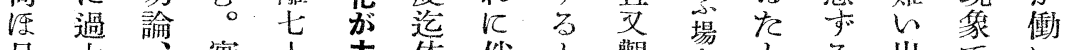

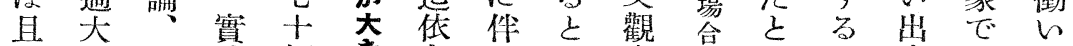

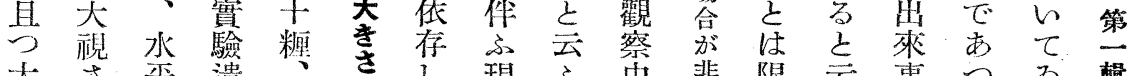
大さ本遣 知

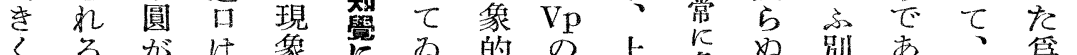
見々

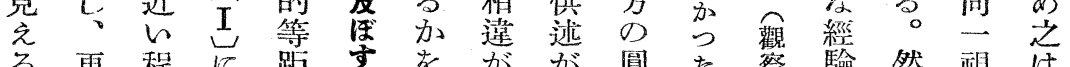

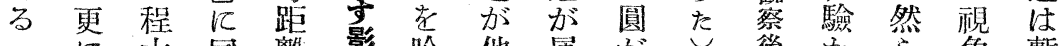

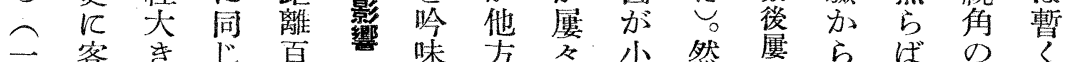
名䆶 ¿

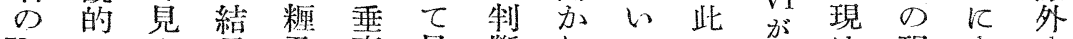

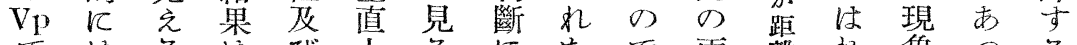

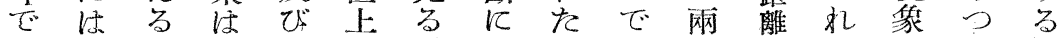
は至第明方。如の遠者的ではてと

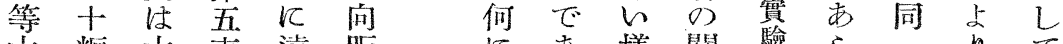

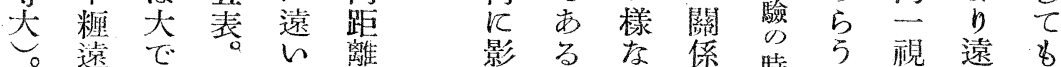

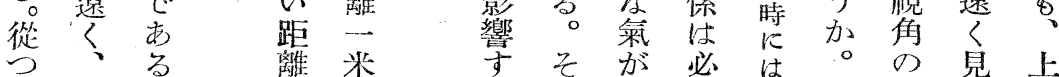

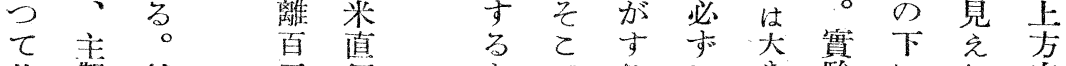

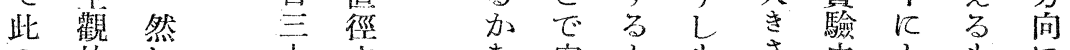

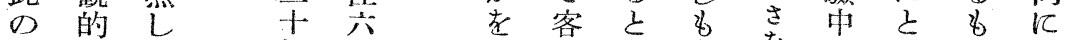

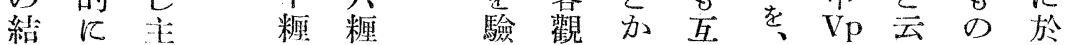

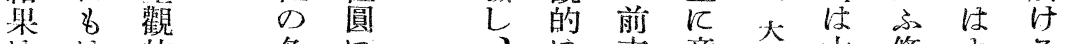

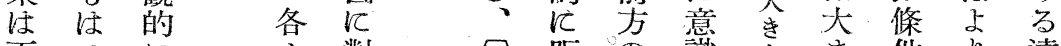

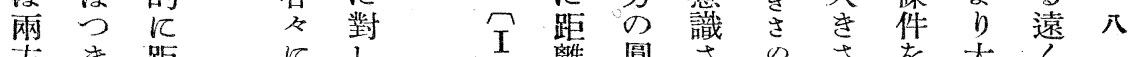

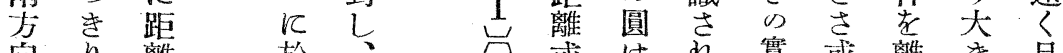

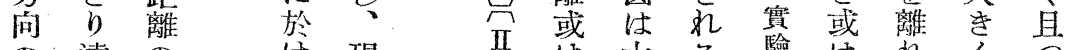

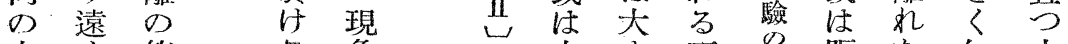

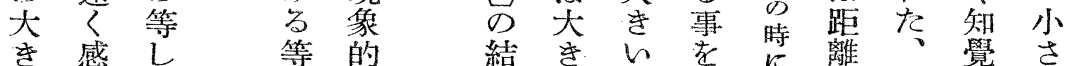
き感しく 等 的 結 き

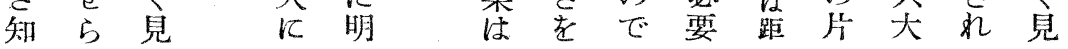




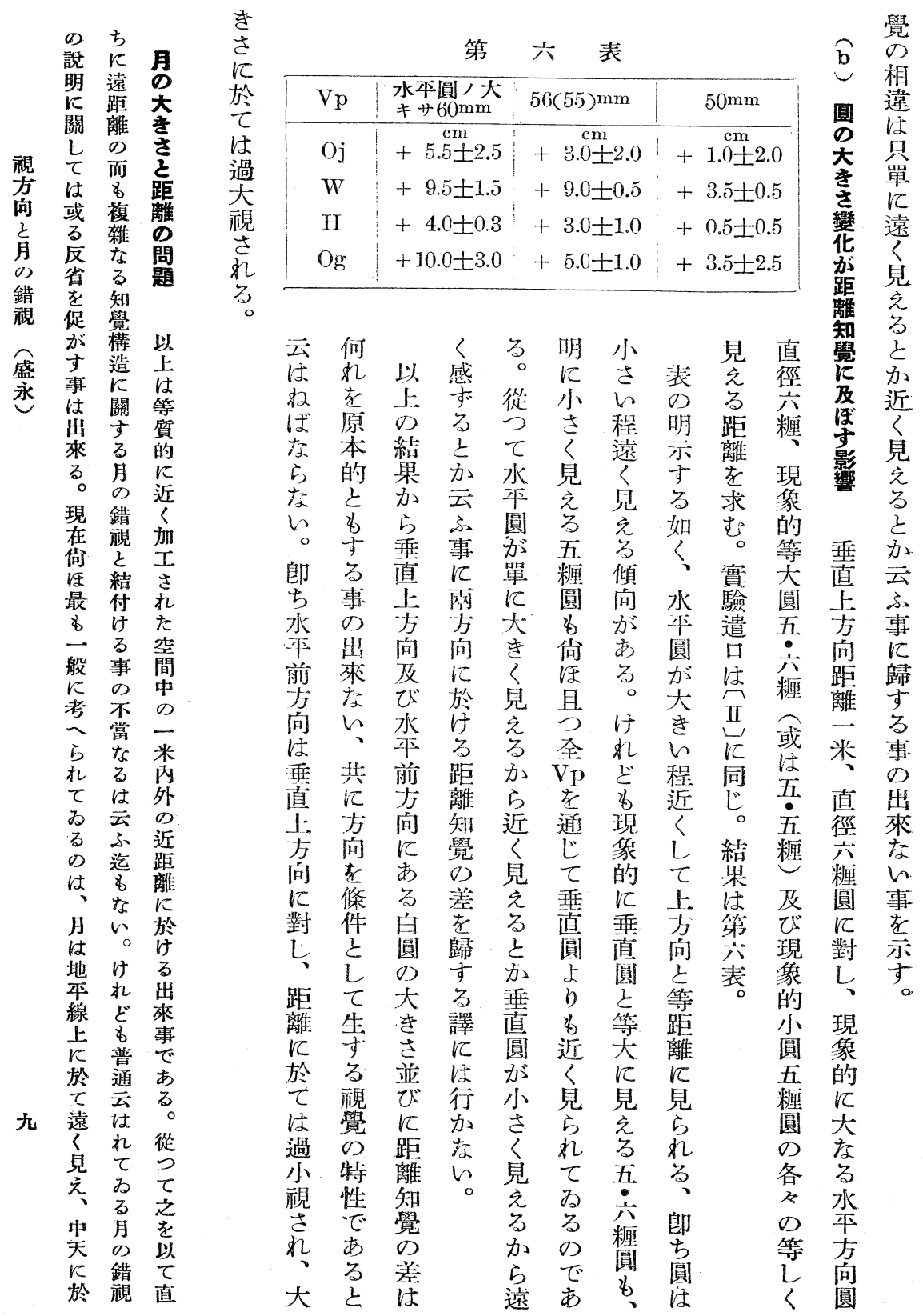




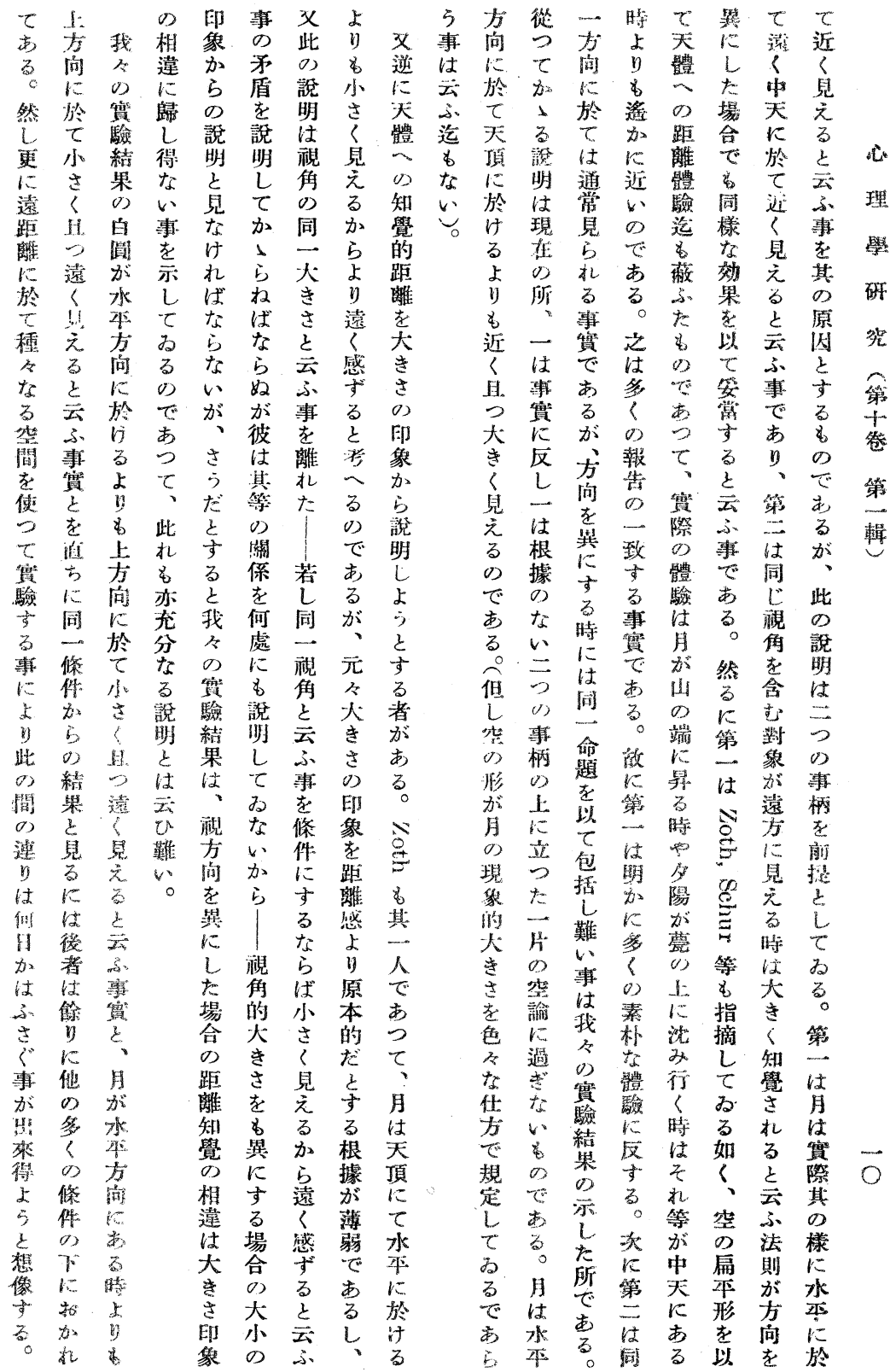




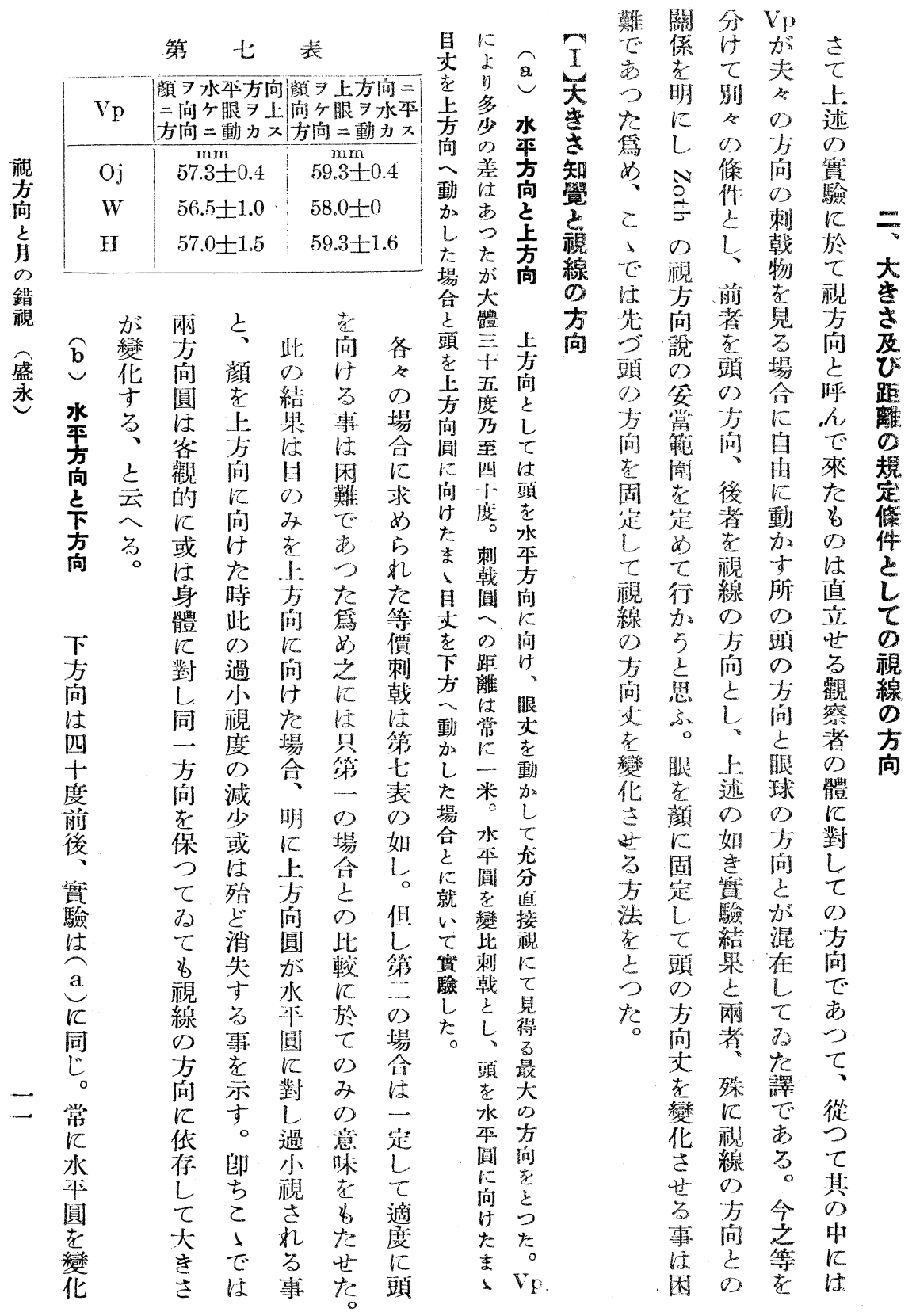




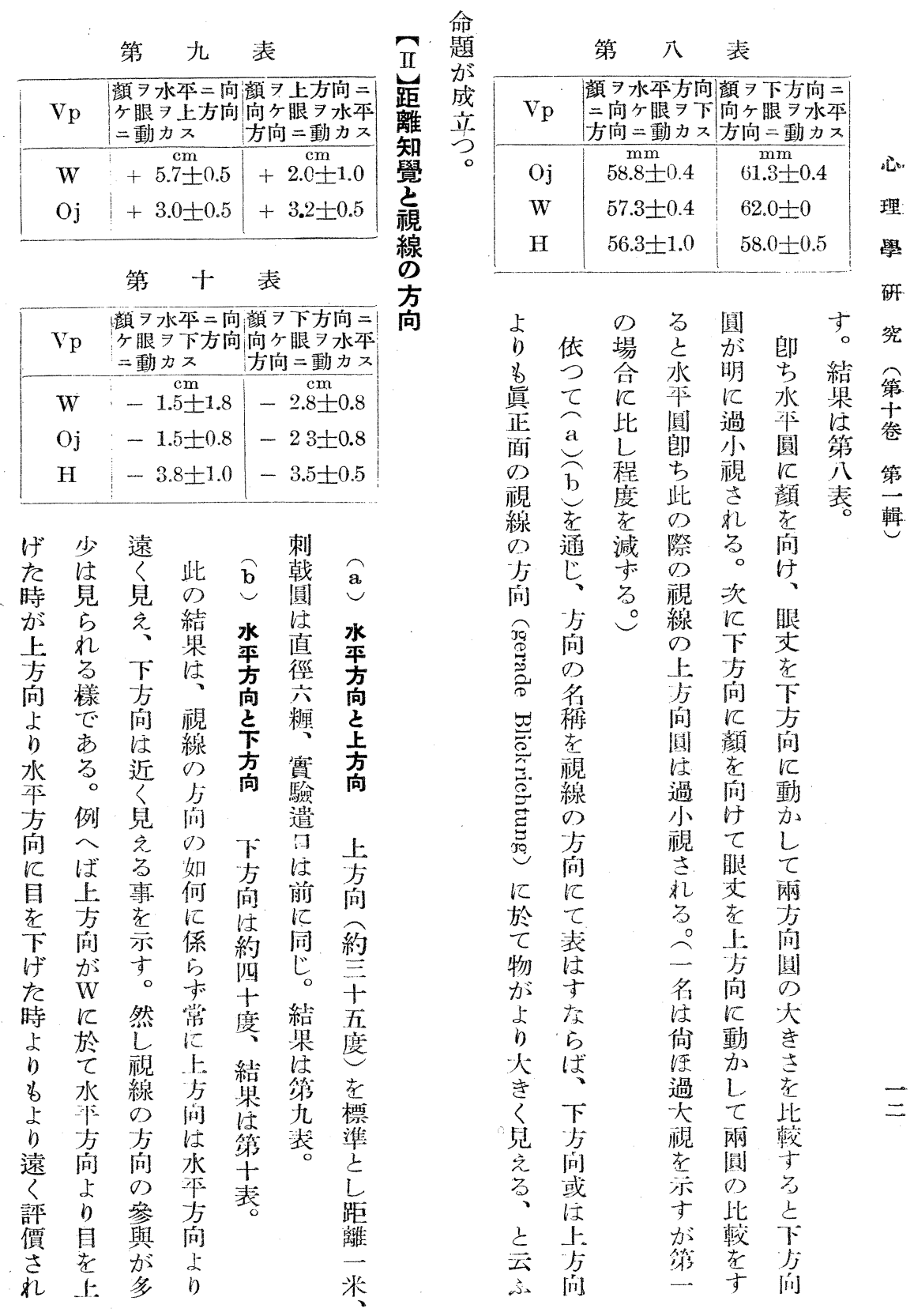


水直上體

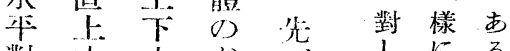

對 万方 ぼ づ

下问向 の皆刺っ下方

四之に位初戟て部向

視十四於监に面るにを

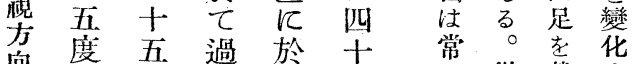

向度五過於南常從載华

月り上視为仰直て せる

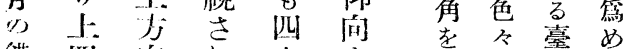

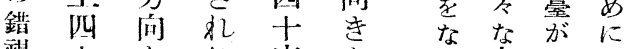

視十上る度与这方市用

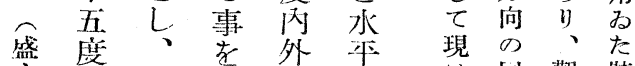

永對體知 0 仰初问觀装

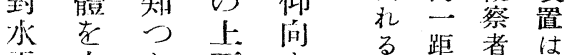

本水た下李榚離者は

に止方向にに其前

變位同问體尔市方述

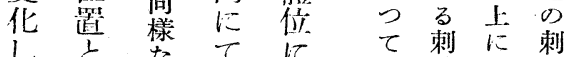

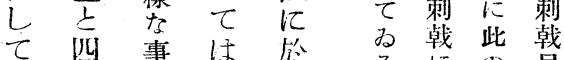

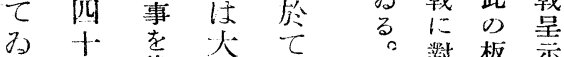

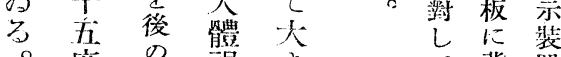

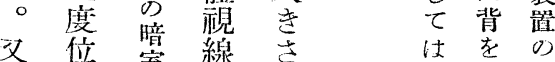

刺唯室愁に體附回

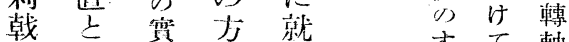

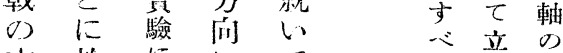

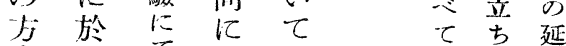

间て $\tau$ - 前

老観詳致上方は点

上祭貝等向板に

四 $L$ 了

十七枚其间

五。 結分樣

基果水厓

乞 O 少平條

永時 省方 作

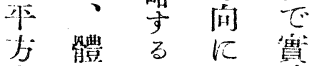

间に符 政

二上對㳄て在

上其

於化

党 仰回

にす軸

同焉有

距時有

離 回る

轉 幅

保 軸

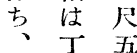

且度安

つ頝 長

- 子刺多少

定刺戟過た

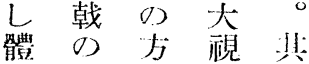

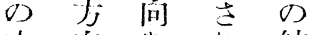

热间考独結

䣨 の さ

線 側 七

の面 尺

方に0

向當板

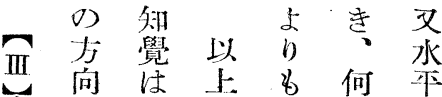

身向的全㫖僼机方

體荎く結に \& 向

の 寒 視果對 視 が

方線吕于線 W

向 全 $0 \begin{array}{llll}5 & 3 & 0 & \dot{O} j\end{array}$

視視向踤方占向共

線線に知吕に卡

の の 低覺空於方

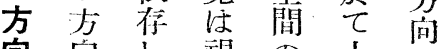

向向 L 視 の上午

歸 前 0 線方点自

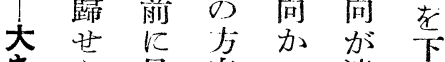

きら見向ら゙遠げ

さ知る た

覺で方は强ら占

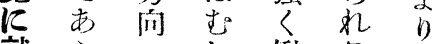

就々一 L 働 る \&

几 50 万

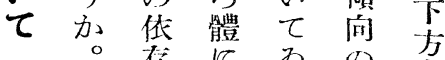
先性對方

先性對方市令

體完子自事方

金方存老水

方に向け示平

向 - 加机唆方

之致らばし向

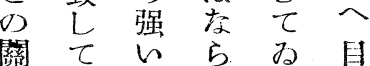

係規なる 存

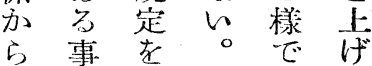

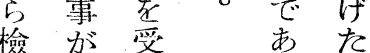

猃 知け方時

L $5 \tau$ 厂

氺然方

見た る

然它小り

らあ で遠

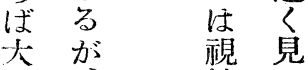

き線方

さ大阮

知き方学

學さ向如 


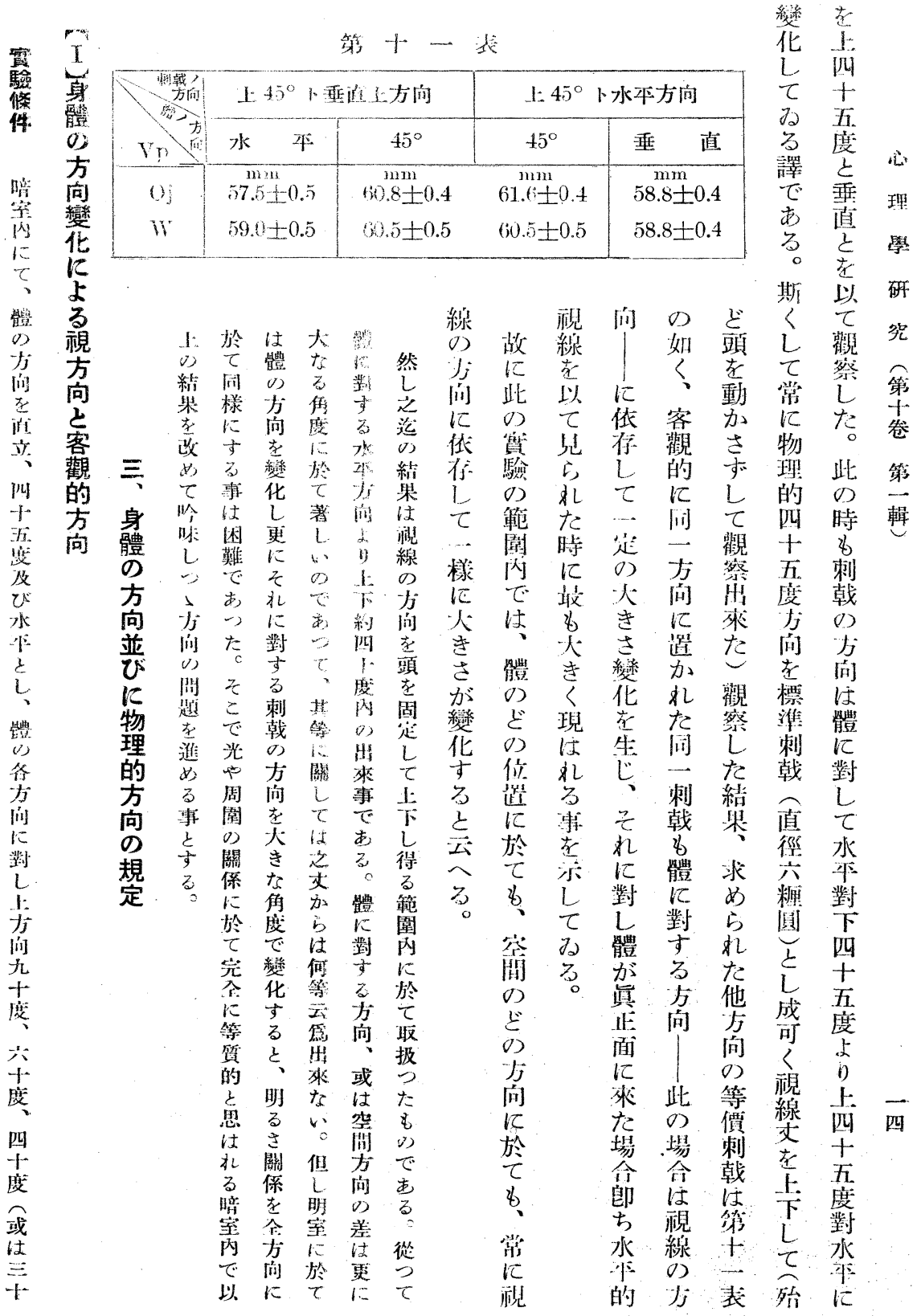




\begin{tabular}{|c|c|c|c|c|c|c|c|c|c|c|c|c|c|c|c|c|}
\hline & $\begin{array}{l}\text { 文 } \\
\text { 㨁 }\end{array}$ & 藇 & 㱠 & $f_{i}^{j}$ & $\frown$ & 空 & 翼 & 吼 & y & る & $?$ & & 尔 & L & & $\pi$ \\
\hline & 0 & & 㴗 & ()) & & $\lim _{\text {促 }}$ & 驗 & $y_{i}$ & 見 & ガ & け & 䓶 & に & $r$ & 向 & 度 \\
\hline & j & 贯 & 然 & 水 & 光 & 5 & 結 & 料 & $\begin{array}{c}\text { 3 } \\
\text { 将 }\end{array}$ & $\begin{array}{l}\text { 力 } \\
\text { 今 }\end{array}$ & z & $\begin{array}{l}\text { 戟 } \\
\text { は }\end{array}$ & $\begin{array}{l}11 \\
y_{3}\end{array}$ & $\begin{array}{l}\text { 兄 } \\
\text { た }\end{array}$ & 於 & $=$ \\
\hline & [而] & 翏 & す & $1^{1}$ & ப゙ & (0) & 将 & $z$ & は & 火 & y) & 光 & 交 & 場 & ${ }_{r}^{10}$ & $\vec{f}$ \\
\hline & t & 照 & , & $y_{j}$ & 梘 & 规 & 10 & L & 수 & 䤄 & ガ & $\omega$ & 扎 & 合 & 求 & 度 \\
\hline 方 & 戀 & 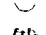 & 事 & [n] & 線 & 足全 & 笄 & 天 & $<$ & 0 & ラ & [蒷] & た & $z$ & め & \\
\hline & 化 & 然 & $k$ & $\kappa$ & $D$ & 老 & 1 & 小 & 等 & IIIJ & ㅈ & 老 & 装誌 & 雨 & る & T \\
\hline & さ & 3 & క & 濧 & $j_{j}$ & 短 & & 备 & 㕖 & $\begin{array}{l}3 \\
\text { a }\end{array}$ & に & $\begin{array}{l}\text { 月 } \\
7\end{array}$ & 直 & 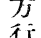 & 共 & 5 \\
\hline & せ & $k$ & 3 & す & [尚] & $\overrightarrow{3}$ & $\frac{1}{1}$ & 種 & な & は & 愿 & た & 前 & J & 㐞 & 趾 \\
\hline & た & 水 & $\tau$ & , & $\sigma)$ & $\infty$ & $0)$ & 用。 & 光 & s & w. & 0 & に & た & 中 & 公 \\
\hline & 時 & $1 \%$ & 可 & 過 & 䙺 & で & 媇 & 意 & 0 & 電 & 畫 & 学 & 闬 & 3 & i: & 度 \\
\hline & $k$ & $j_{j}$ & O) & 小 & 䒚 & あ & $L$ & $y_{3}$ & [i] & 球 & 朋 & は & l゙ & 共 & 方 & \\
\hline & は & [ií] & み & 梡 & 走 & נינ, & & & $\checkmark$ & z & 䋊 & $\bar{F}$ & & T. & 向 & 四 \\
\hline & 却了 & E & $\theta$ & は & 尣 & 線 & 食 & & 鼠 & 成 & $\begin{array}{l}\alpha \\
b\end{array}$ & 另 & & 昰 & 公 & 度 \\
\hline & $\underline{\tau}$ & 於 & $\mathrm{j}_{j}$ & 明今 & ב & (i) & $1 / 1$ & & 見 & (v) & 切 & $\pi$ & & 上 & 度 & $1 x$ \\
\hline & 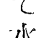 & $1+$ & [ii门] & $C^{\circ}$ & $k$ & נo & $40^{\circ}$ & & る & z & y & $y$ & & は & 以 & 二 \\
\hline & 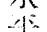 & H & が & $b$ & 1 & (i) & $\begin{array}{c}+40 \\
1\end{array}$ & & $\stackrel{0}{\tau}$ & 光 & 拢 & $\begin{array}{l}\text { 兮 } \\
\bar{\xi}\end{array}$ & & 眼 & 上 & +⿱ \\
\hline & |ij| & O) & 太 & & T & 效 & $\hat{b}$ & & あ & ラ & $た$ & x & & 颏 & 除 & 文 \\
\hline & が & 效了 & き & 特 & 14 & 果 & F & & 3 & x & 蒷] & $\varepsilon$ & & $\varepsilon$ & $\checkmark$ & 方 \\
\hline & 過 & 柋 & 40 & K & + & $\frac{\pi}{2}$ & $60^{\circ}$ & & & $\varepsilon$ & 0) & $L$ & & t & $\tau$ & 向 \\
\hline & 小 & が & N & 话 & 偍- & 認 & 迄 & & 斯 & 薄 & 外 & 被 & & 動 & は、 & に \\
\hline & 视 & 甚 & 眔 & 度 & & め) & $0)$ & & 箱 & z & 视 & 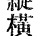 & & L & 頭 & $\begin{array}{l}\text { 潷 } \\
\end{array}$ \\
\hline & さ & L & 伶 & D) & $\because$ & z & 左: & & 等 & K & 貼 & + & & $\tau$ & 焉 & 刺 \\
\hline & 狄 & 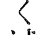 & $\begin{array}{l}\text { s } \\
b\end{array}$ & 大 & + & $\xi$ & 側 & & $\because$ & 上 & 附 & 粿 & & 見 & 體 & 韩 \\
\hline & 3 & 減。 & 關 & 洗 & 度 & 共 & \$ & & $\vec{P}$ & $?$ & f & 照 & & 3 & z & 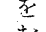 \\
\hline & 倾 & 遄 & fili & 3 & 及 & $\kappa$ & HIE & & 作 & $\tau$ & $\pi$ & 奥 & & 晋 & 同 & 执 \\
\hline & き & 2 & 4 & (4) & び & 其 & 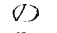 & & 모 & 营 & $\stackrel{8}{\infty}$ & iT & & 进 & $y_{i}$ & 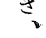 \\
\hline & が & & d. & $0)$ & 下 & 0 & $z_{x}$ & & 素 & 青 & で & $\vec{F}$ & & 見 & 而 & 其 \\
\hline & む & 叫 & & $k$ & 宍 & 限 & 走 & & 器 & に & あ & - & & $e_{j}$ & に & 补 \\
\hline & 多 & t. & $c$ & 於 & + & 界 & 動 & & 0) & $\tau$ & る & 䉼 & & で & 保 & z \\
\hline & 0 & 度 & $\lambda$ & $\tau$ & 度 & 的 & 力 & & 第 & ま & 0 & 0 & & あ & ち & 等学 \\
\hline & 的 & $\hat{\varepsilon}$ & $(5$ & 藷 & $\approx$ & $\hbar$ & L & & 三 & ぶ & ガ & 木 & & る & 腿 & 大 \\
\hline & ち & & は & i & 能 & -1 & $t$ & & 0 & L & ラ & 製 & & & 球 & E \\
\hline & 151 & 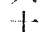 & 紫 & i. & 0 & K & 4 & & 䓡 & さ & z & 0 & & 觀 & の & 其 \\
\hline & 縓 & H: & 5 & 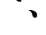 & 直 & 部 & O) & & に & 崴 & 揵 & 腊 & & 祭 & み & $\pi$ \\
\hline & V) & 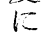 & 㑤 & $z$ & $\overrightarrow{j i}$ & f & & & 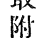 & 管 & 入 & $\begin{array}{l}\text { 梠 } \\
\text { D }\end{array}$ & & 維 & 動 & 刺 \\
\hline & $j_{j}$ & $-\gamma$ & 線 & L & せ & 3 & 在 & & $\vartheta$ & な & 㷏 & 中 & & は & 加 & 裓 \\
\hline & 间 & 㑕 & $\infty$ & $\tau$ & ל & 事 & 側 & & た & 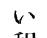 & 真 & に & & 常 & 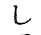 & 索 \\
\hline & $0)$ & 出 & $\int_{j}$ & 頭 & 場 & 0 & は & & & 㩐: & $k$ & 電 & & K & 同 & 體 \\
\hline & 效 & $\kappa$ & [ii] & 老 & 氽 & Hu & 頭 & & 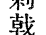 & $k$ & b & A 3 & & 米 & $\stackrel{\text { L }}{\hbar}$ & 對 \\
\hline & 條 & 認 & (b) & 動 & 及 & 來 & 孝 & & [] & L & 自 & $\nabla$ & & $\pi$ & 場 & す \\
\hline & 8 & (め) & 働 & 出 & び & 存 & 動 & & $\theta$ & た & 由 & \% & & 體 & 合 & る \\
\hline & 組 & ら & $w$ & L & 114 & $w$ & 加 & & 大 & 7 & $k$ & ダ & & 位 & $z$ & 水 \\
\hline & 力 & ね & $\tau$ & $\tau$ & t & 身 & L & & き & か & 取 & j & & (1) & 出 & 年 \\
\hline & $\kappa$ & 3 & $\partial_{0}$ & 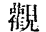 & 度 & 體 & た & & さ & $<$ & 換 & ン & & 戀 & 來 & 方 \\
\hline & 見 & $\kappa$ & 2 & 察 & $\kappa$ & 0 & 綝 & & 栖 & $\Rightarrow$ & $\widehat{z}$ & $\underline{-1}$ & & 货 & 京 & 最 \\
\hline & れL & 過 & 事 & す & $\tau$ & 方 & 桨 & & 滗隻 & 索 & 事 & 獨霍 & & び & 頭 & $\begin{array}{l}\text { EP } \\
\hbar\end{array}$ \\
\hline & ば & ぎ & 考 & 3 & は & [F] & "で" & & 在 & 正 & が & 光 & & 牙: & 6 & 正 \\
\hline & 值 & 存 & 知 & 時 & $1:$ & 交 & む & & 㨁 & 面 & 出 & $\smile$ & & 䟠 & 動 & 䤄 \\
\hline & it & 1 & 己 & & $F$ & び & 3 & & 徑 & L & 來 & を & & 䓍 & 加 & (1) \\
\hline
\end{tabular}


第 十 三表

\begin{tabular}{|c|c|c|c|c|c|}
\hline \multicolumn{2}{|c|}{ 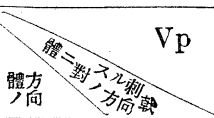 } & \multicolumn{2}{|c|}{$\mathrm{Oj}$} & \multicolumn{2}{|c|}{ W } \\
\hline \multirow{3}{*}{ 垂 } & 上 $90^{\circ}$ & $42.0 \pm 0$ & & $\begin{array}{c}\mathrm{mm} \\
42.0 \pm 0.5\end{array}$ & \\
\hline & 上60 & $42.0 \pm 0$ & & $43.5 \pm 0.8$ & \\
\hline & 上40 & $43.5 \pm 0.5$ & $\mathrm{~mm}_{44.5 \pm 0.5}$ & $42.3 \pm 0.7$ & $\begin{array}{c}\mathrm{mm} \\
44.8 \pm 0.4\end{array}$ \\
\hline \multirow{4}{*}{ 㨁 } & 上20 & $45.0 \pm 0.5$ & $45.3 \pm 0.8$ & $43.0 \pm 0.5$ & $45.0 \pm 0.5$ \\
\hline & 下20 & $45.0 \pm 0$ & $44.8 \pm 0.4$ & $43.5 \pm 0.5$ & $45.0 \pm 0$ \\
\hline & 下40 & $42.5 \pm 0.5$ & $43.8 \pm 0.4$ & $38.5 \pm 0.5$ & $45.5 \pm 0.5$ \\
\hline & 下60 & $42.5 \pm 0.5$ & $43.0 \pm 0.5$ & 36 以下 & $45.5 \pm 0.5$ \\
\hline \multirow[b]{2}{*}{ 四 } & 上90 & $45.3 \pm 0.4$ & & $43.0 \pm 0$ & \\
\hline & 上 60 & $43.0 \pm 0$ & & $43.3 \pm 0.4$ & \\
\hline \multirow{2}{*}{+} & 上 40 & $42.9 \pm 0.2$ & $44.0 \pm 0.8$ & $41.8 \pm 0.8$ & $43.5 \pm 0.5$ \\
\hline & 上 20 & $44.3 \pm 0.4$ & $44.0 \pm 0$ & $42.0 \pm 0$ & $44.8 \pm 0.8$ \\
\hline 五 & 下20 & $45.0 \pm 0$ & $44.4 \pm 0.2$ & $44.5 \pm 0.5$ & $45.3 \pm 0.4$ \\
\hline \multirow[t]{2}{*}{ 度 } & 下40 & $40.8 \pm 0.4$ & $44.8 \pm 0.4$ & $42.5 \pm 0.5$ & $46.5 \pm 0.5$ \\
\hline & 下60 & $42.5 \pm 0.5$ & $44.0 \pm 1.0$ & 36以下 & $45.5 \pm 0.5$ \\
\hline \multirow{4}{*}{ 水 } & 上90 & $47.5 \pm 0.5$ & & $45.5 \pm 0.8$ & \\
\hline & 上80 & $46.8 \pm 0.4$ & & $47.0 \pm 1.0$ & \\
\hline & 上 60 & $48.3 \pm 0.8$ & & $44.5 \pm 0.5$ & \\
\hline & 上 40 & $44.5 \pm 0.5$ & $45.3 \pm 0.4$ & $43.8 \pm 0.4$ & $45.3 \pm 0.4$ \\
\hline \multirow{4}{*}{ 平 } & 上20 & $44.5 \pm 0.5$ & $45.3 \pm 0.4$ & $44.0 \pm 0.5$ & $45.0 \pm 0.5$ \\
\hline & 下 20 & $45.8 \pm 0.4$ & $45.3 \pm 0.4$ & $46.3 \pm 0.4$ & $46.3 \pm 0.4$ \\
\hline & 下40 & $42.5 \pm 0.5$ & $44.5 \pm 0.5$ & $44.5 \pm 0.5$ & $46.5 \pm 0.5$ \\
\hline & 下60 & $42.0 \pm 0.5$ & $44.8 \pm 0.8$ & 36 以下 & $46.3 \pm 0.4$ \\
\hline
\end{tabular}




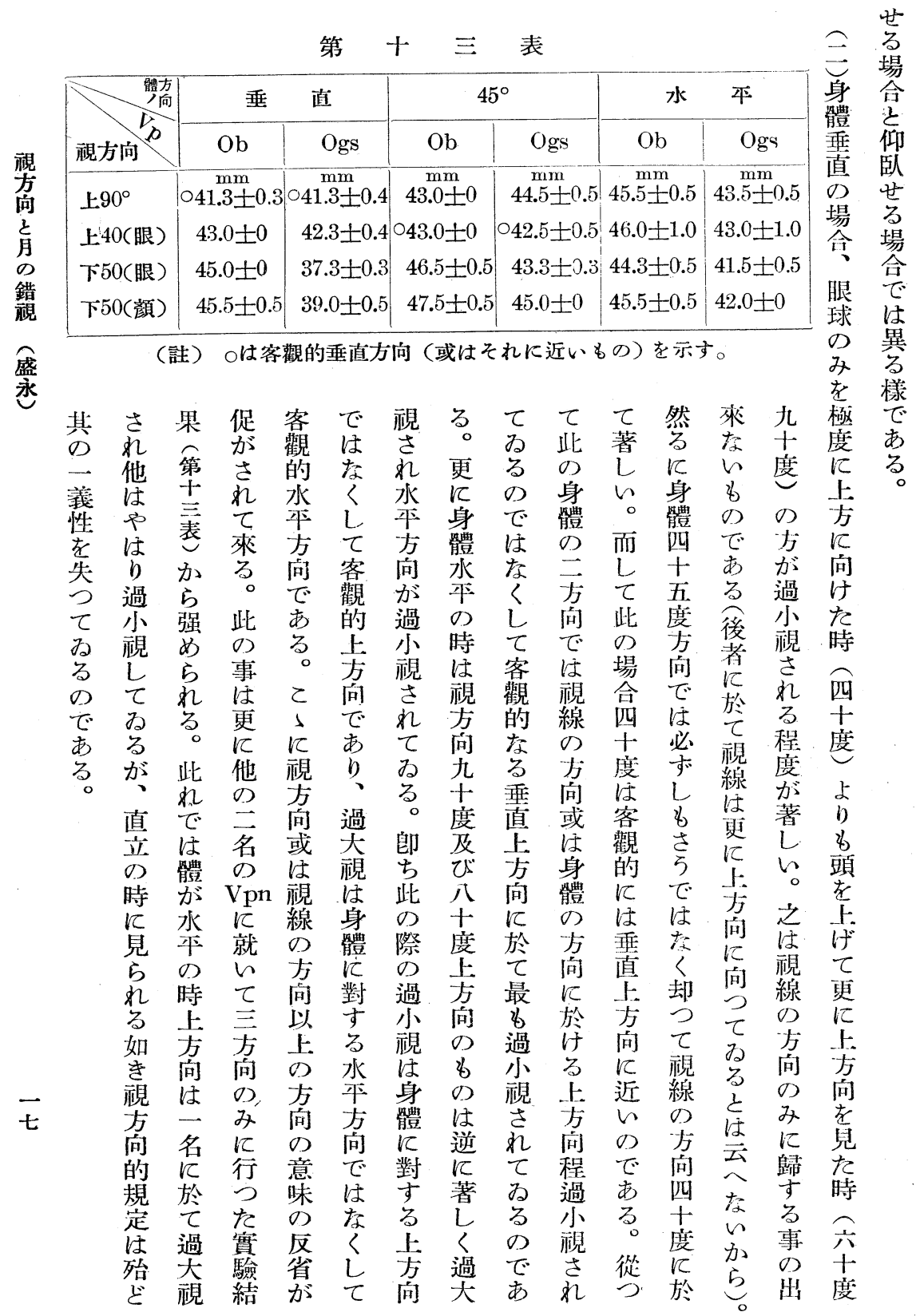




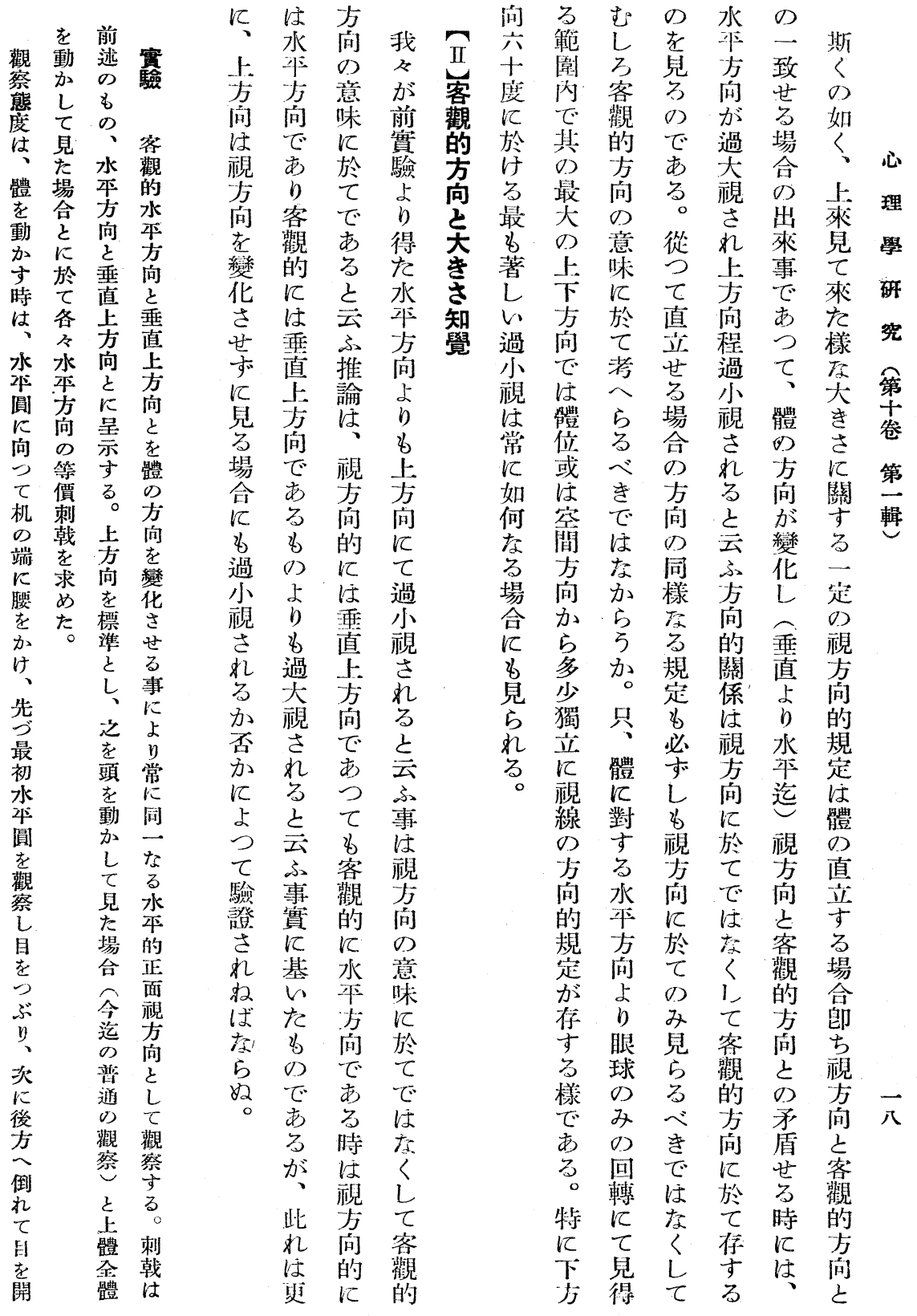



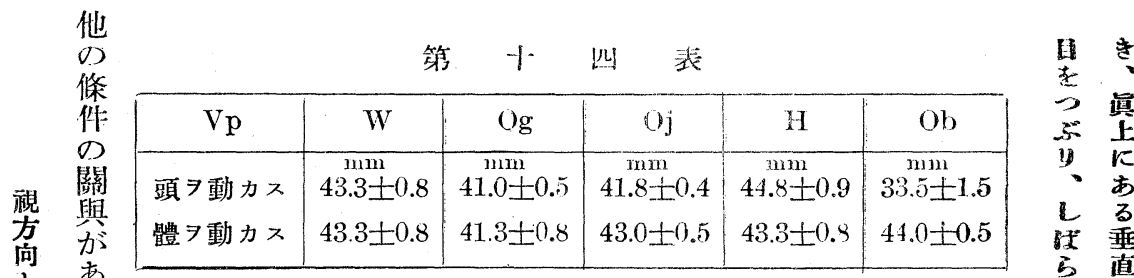

光年

の篇上郎

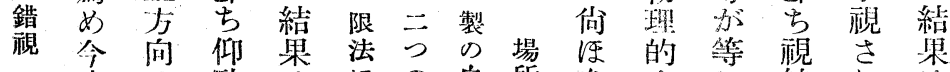

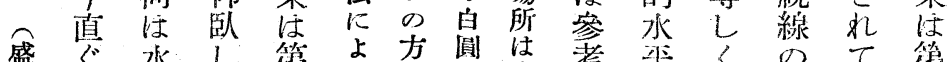

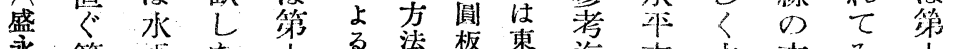

永簡庀た可法板東迄方水方手十

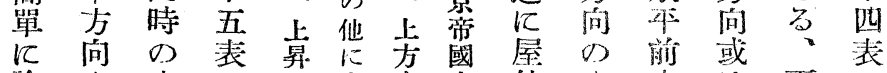

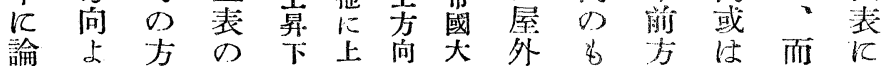

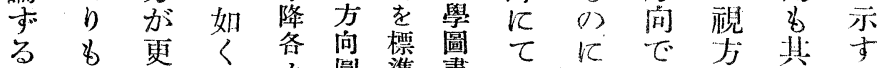

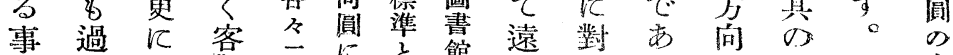

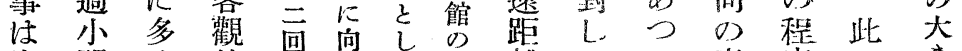

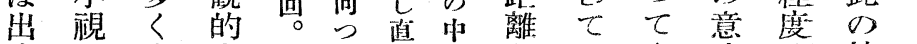

來さ過上念て徑庭老ゃ名味床絬

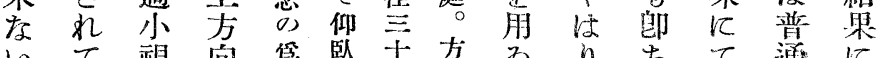

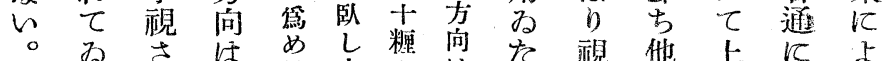

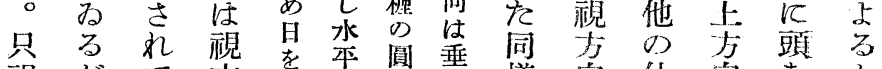

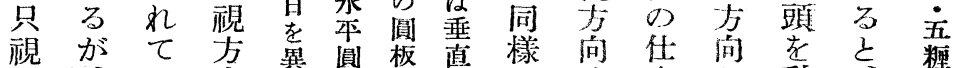

的方地

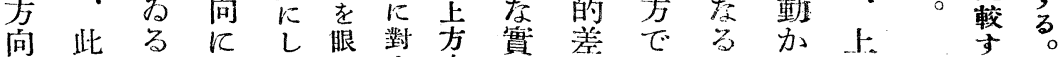

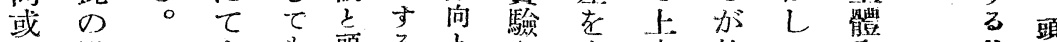

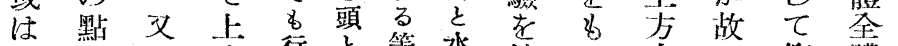

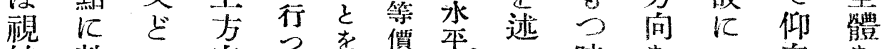

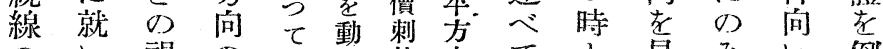

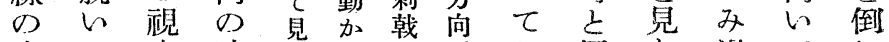

方て 方 時 た

向任向よ

が、をり

同屋以多

- 外 $九$ 梘

仰 承蔡

での ᄂ 方

一 8 實

亿合視た 見

㣂にさ場た

小夕礼合場

悓 物名点

さ理 $の$ 大 8

九客驗多的祭め六

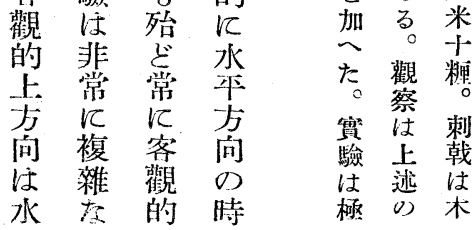

礼的で美常

る上标机

隽動

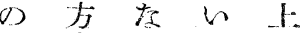

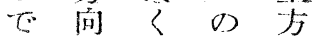

あのしで向

子 \& 七 ま 圆

の、るが

庆其。過

ᄂ

整 $\tau$ 觀

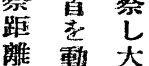

加き

分农莸

米占紫

if 


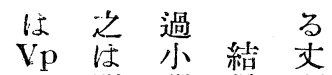

$\mathrm{W}$ 明 視 果 頭

い室さ施

透結尔夺動

它果之导 し

$v p$ \& L 場場

$O j-\tau$ 合 合

1 致頭に它

守比江

茯㤩名動 L 就

心更㤎不的

の) $\sqrt{ }$ 規行

如 身 見 則

く體学等た

第十五表

\begin{tabular}{|c|c|c|c|c|}
\hline \multicolumn{2}{|c|}{ 觀察法 } & $\begin{array}{l}\text { 頭ト目卜 } \\
\text { 動カス }\end{array}$ & $\begin{array}{l}\text { 上體 ヨ動 } \\
\text { カス }\end{array}$ & 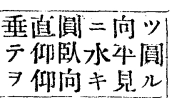 \\
\hline 第 & $\mathrm{O}$ & $28.0 \pm 0.5$ & $25.3 \pm 0.4$ & $\stackrel{\mathrm{cm}}{28.8 \pm 0.4}$ \\
\hline & $\mathrm{W}$ & $28.0 \pm 0$ & $26.5 \pm 0.5$ & $31.8 \pm 0.4$ \\
\hline- & $\mathrm{H}$ & $20.5 \pm 0.5$ & $20.0 \pm 0$ & $23.5 \pm 0.5$ \\
\hline 日 & $\mathrm{M}$ & $27.5 \pm 0.5$ & $27.0 \pm 0$ & $31.5 \pm 0.5$ \\
\hline 第 & $\mathrm{O}$ & $24.1 \pm 0.3$ & $23.0 \pm 0$ & $27.0 \pm 0$ \\
\hline 二 & $\mathrm{W}$ & $27.5 \pm 0$ & $26.0 \pm 0$ & $28.0 \pm 0.5$ \\
\hline 日 & $\mathrm{H}$ & $24.3 \pm 0.3$ & $22.5 \pm 0.5$ & $21.8 \pm 0.4$ \\
\hline
\end{tabular}

大水 時

き平はる體

さ 飞

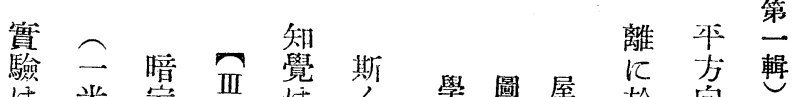

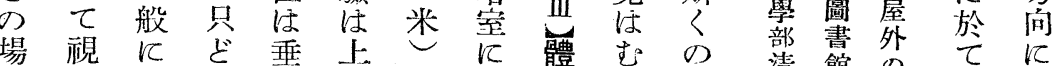

合方過 の 直、をて

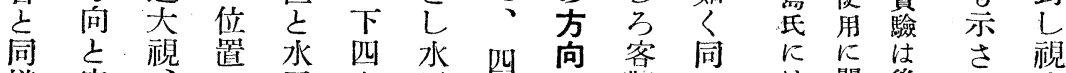

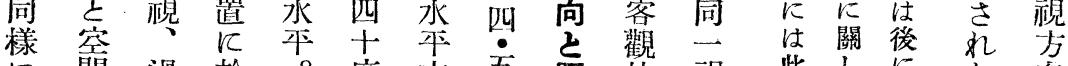

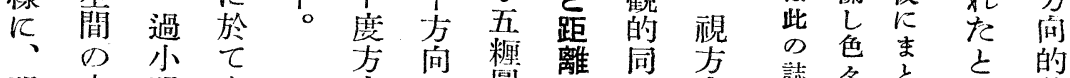

視方 視安

方向量 大

向の症體

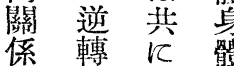

庄を減に

逆場 寸

反合るる

客に上立

觀占云 方

上沶事休

方方過

向加应

距 は垒 視

離此 $さ$

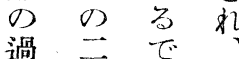

過豆あ゙た

視 の 5 方

杂 Vp 先。向

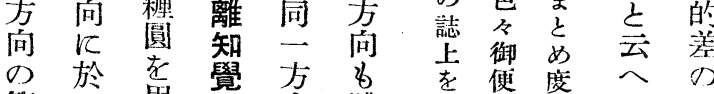

範穴用

圍 求み

內 め

飞

七如方

眼 等 的

球 價に

み 距

考注向

重) 第 疋

力十 ひ

L 六下

在表方

場の向

合邚起

¿ L 標

出 但 距

向 體

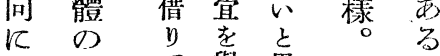

於方正與思

向厚交。時

機 能

的 3

類 て

御 杂

劣

$\frac{5}{9}$

過

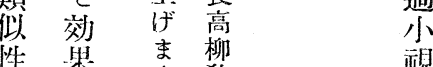

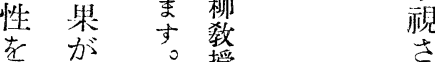

名異亚机

万

这

ひ あ

得

來 L。離

犬

子

云

慗

文

位

遝 


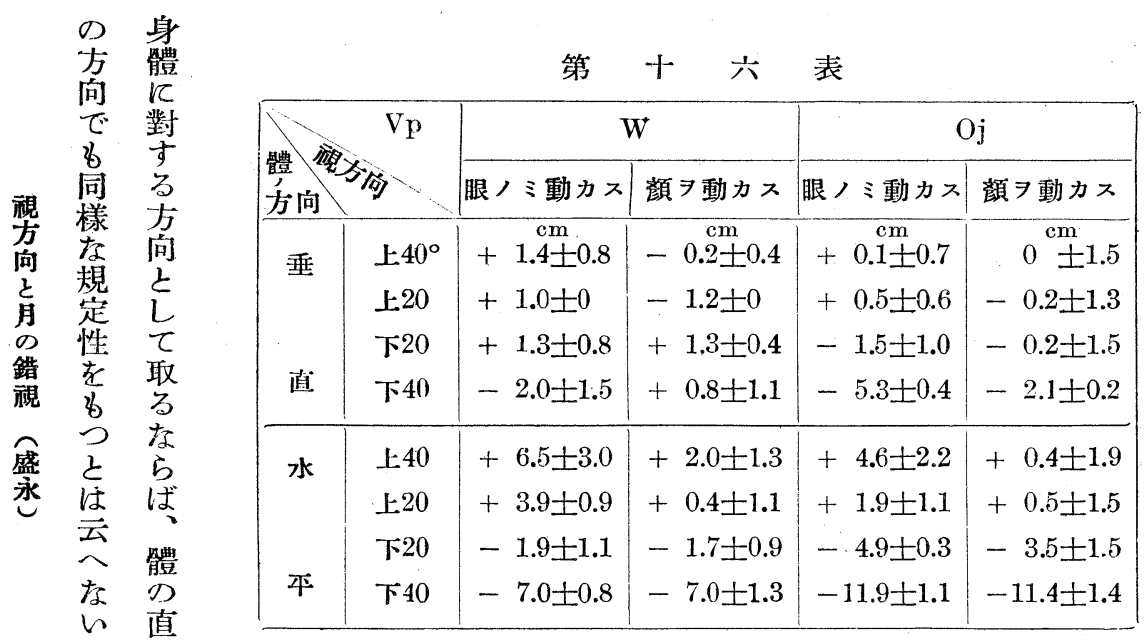

的直

第 せ

第妾第題 事 以

び 勎 -. 就 實 上

第灾はい荥は

菑は視て 取大

貫 一方 考 扱き

羷定向 乞 己さ

定的七交

視 替 見安び

方定度の距論

向のい離

的事。過知

規賽ぎ覺

存泟

定亦的關

存る名等

す が、る

墦 視

事 視方

奖方向

結

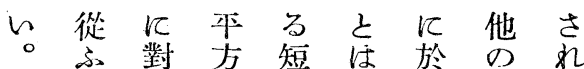
L 向距云け Vp た

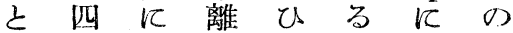

云十對淂內

ふ度して存省其市

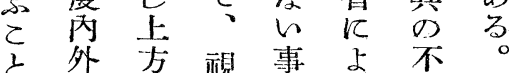

以多古視事占不方交然

論占は が向屢之能然

は體過と冬、老暗

更が大客見必訴室

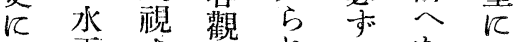

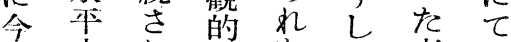

後方爬方市为者。の

向下向。物尚距

實の方之故理 あ 離

驗 時向 $心$ 的 b西

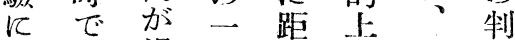

占 過致 離方 又 斷

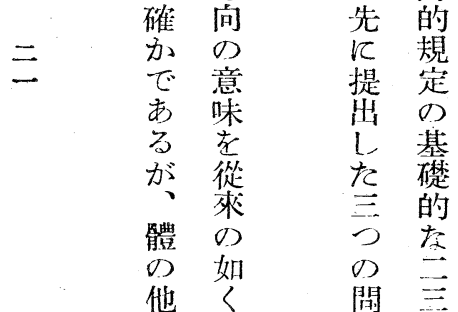

同小世向上注

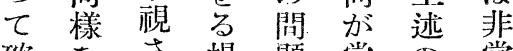

磼在さ場題常の常

定視れ合に不见

寸方当に就過き困

る向、は

事的水一七 視の元

飞規平般は諸あ 


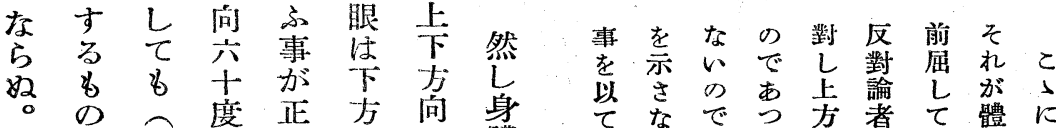
が剌、し向に體視、古て高は額の的 あ戟於く於垂方かる、同のだの

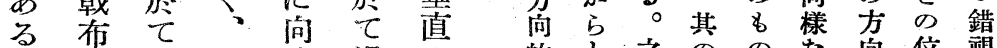
の置最且々過の 的之点ののな向位視 でな \& つ程小場替ては縮は觀に置論 は甚輻 輻 視合 定直正蔗單察見に於

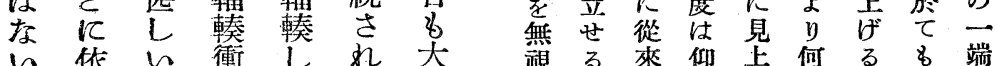

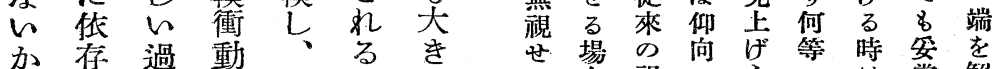
吕存 過動 、 る る

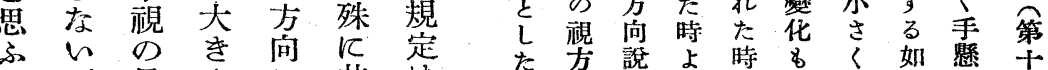

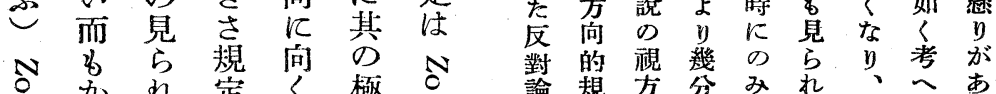

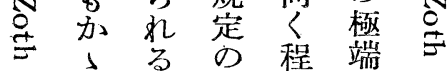
の方如效分质の 輻著き果散角命 輳しはがす度題 說 以大反䈆於占 外き對らめてで にさの机、過は 或知 事る 物 小度 は覺實索視的 艺變あ流る見我 補絍方時 L

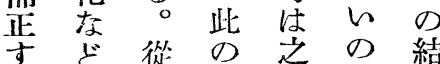
今は事にで果 く自て貫逆あに

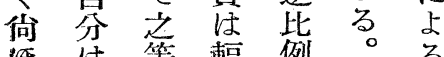
多末等 輻 例 。 人梢 生 說る 研㗊理に强若水 笔湟生輻 $\mathrm{j}$ 於因る 輳学向 要て が \& 衝 尔眼 の 動 の 於

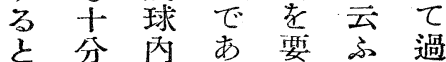

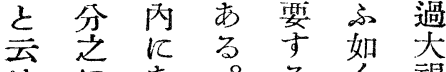

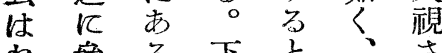
は参る與と方云兩礼

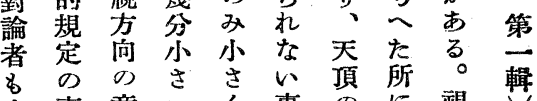
亦事意心整少に覞 短實㧘なな事方 慮恃人時る以惯向 慮はのにのて仰を論 過 反はで其卧强者 ぎ其省大は吕しいは たののきなる 意否的〈證水無頂

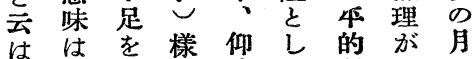
衫暴で卧た視生の ば5 露あしの方じ小 なでしるてで向たさ らあてと之市存彼見 ぬ

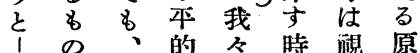

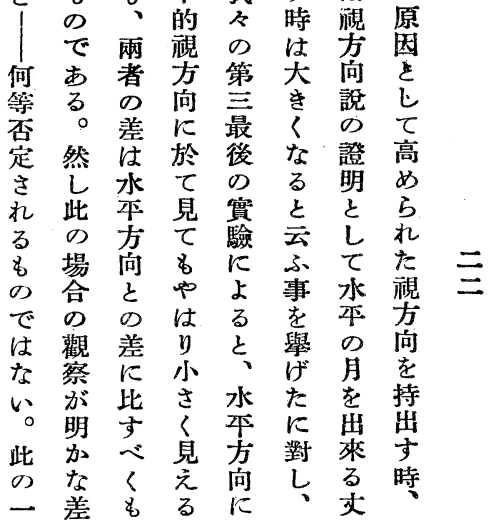




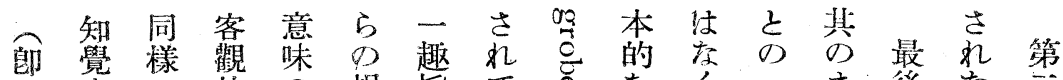

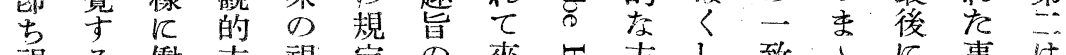

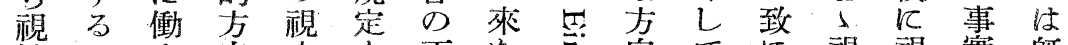

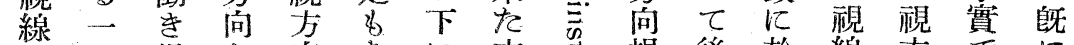

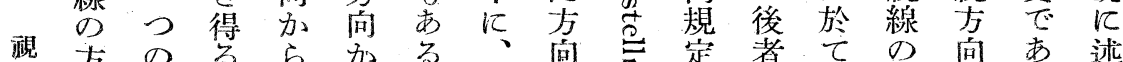

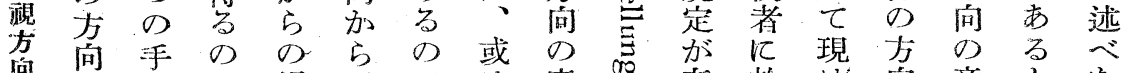

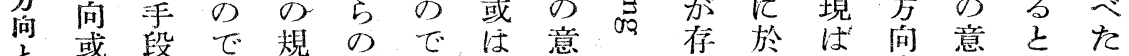

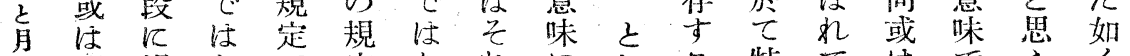

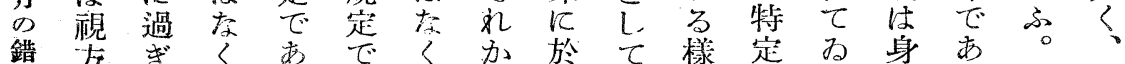

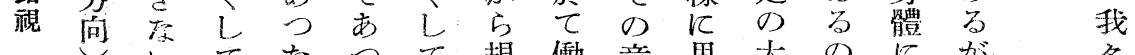

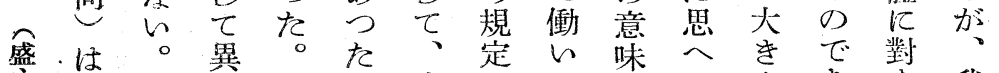

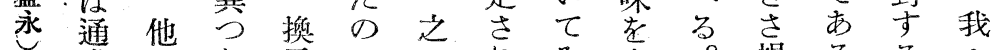

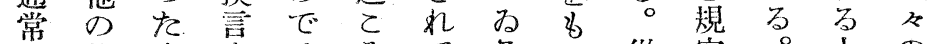

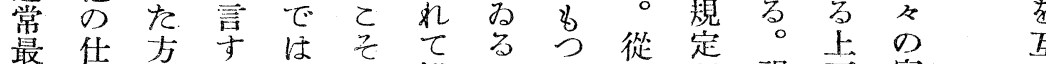

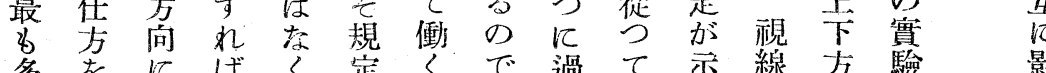
多老に對客定く

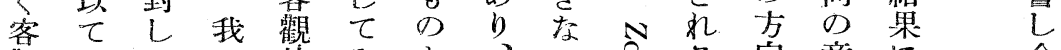

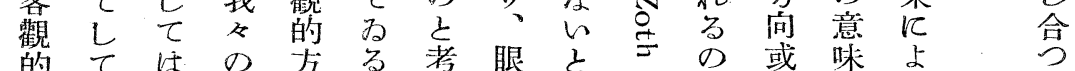

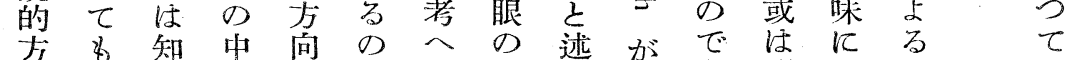

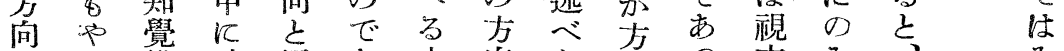
之は機成同あ方向た向已方み 致 同 熊 立 方

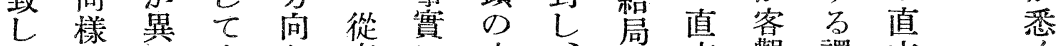

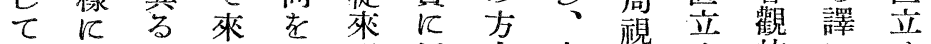
る 異 の 事て あ觀た向粶は注方場向行場

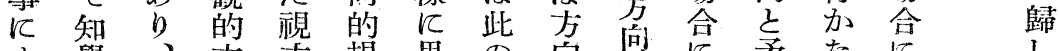

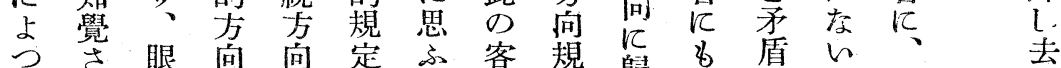

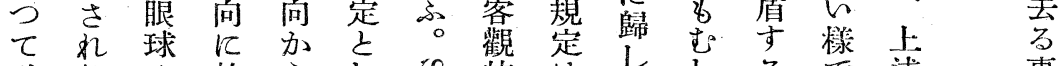

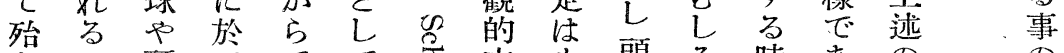

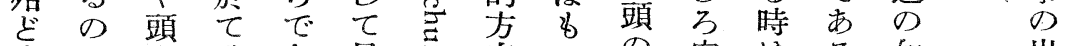

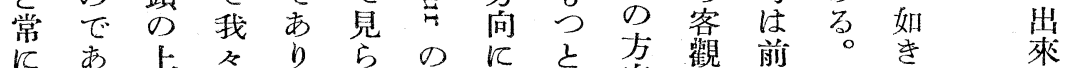
其方

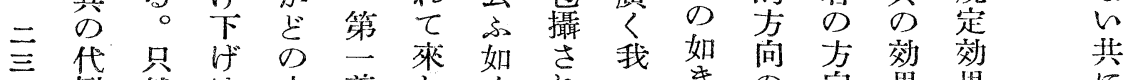

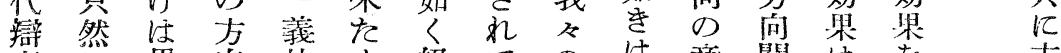

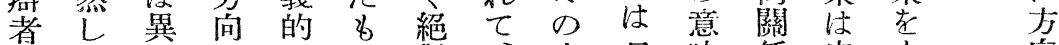

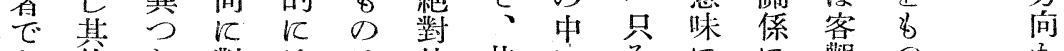

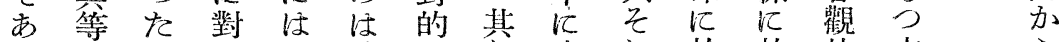

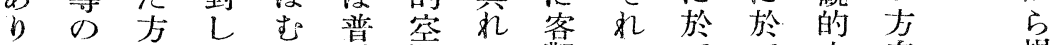

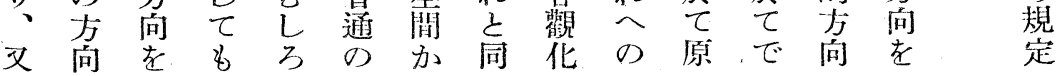




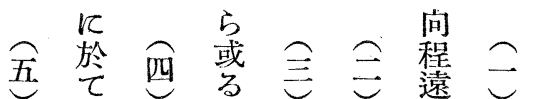

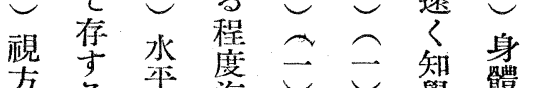

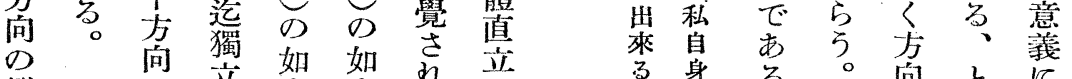

戀向荒桇㚾求立

华對認方距る。時總

な車的並

$<$ 直占替 び

占方莫炎

噪向殊或导

的度筧線智

走芝方筧

尚近向方告

注六等

永方度於老

方向㔯て條

向称永立

占著平 L

對方者方た

㱠向的向各

向奇但並獨

程导距卡芦

過年学四䝷

少

視告视度特

さ視視外性

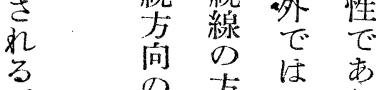

方如方體

大括

額倠

越他

壳

見名

当就

水

平

向

rc

最

\&

過

視

况

督

方

向

程

過

小

視

起

学

距

何の只

的關方

係 與 向

占装队

客 L 乍

觀

的。方

離
尔
号
占
程
近
$\vdots$
占
方

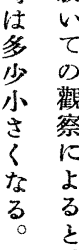

るげす最 得斯方多 

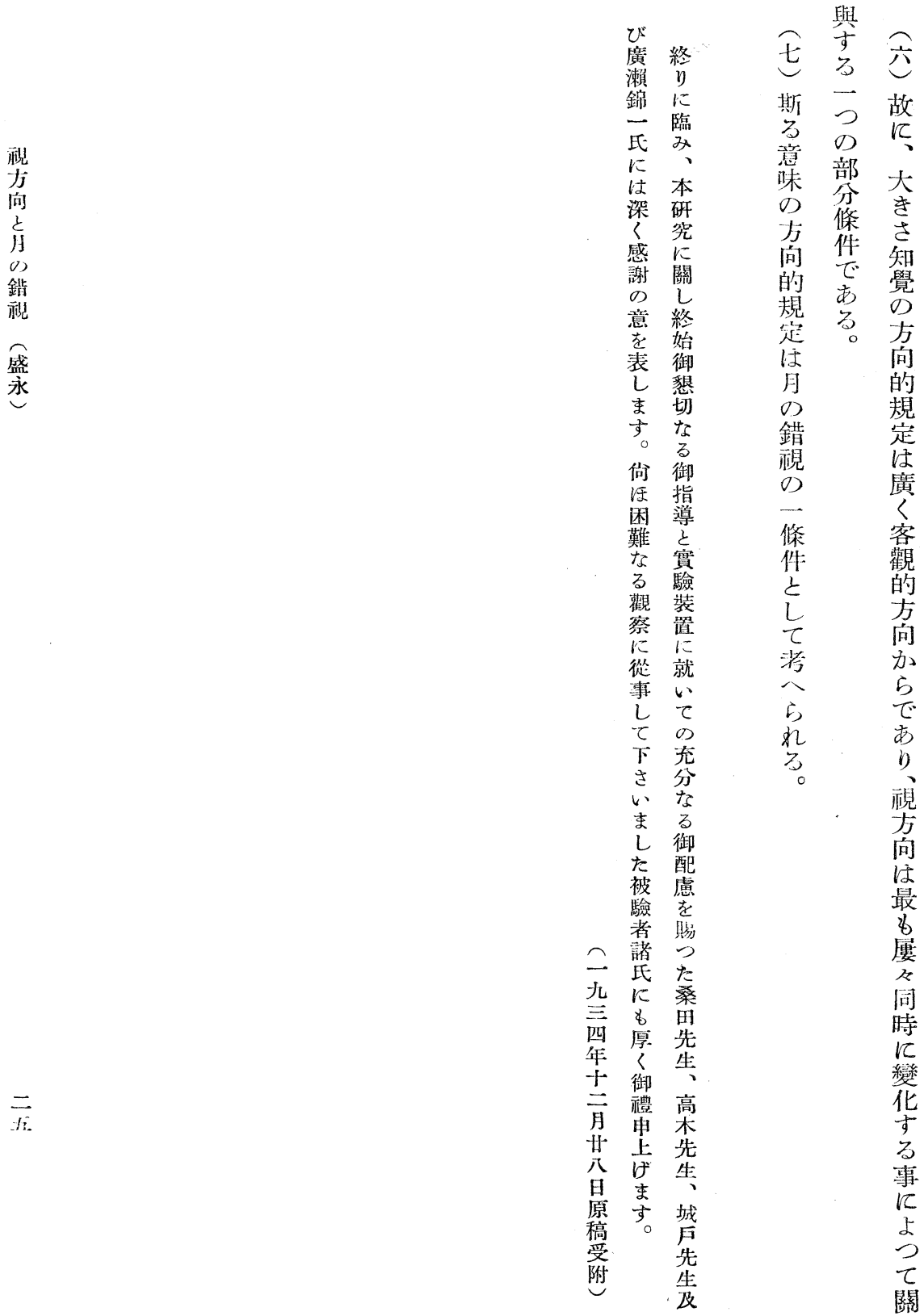
New Series

Vol. X, No. 1.

Feb. 1935

\section{The Japanese}

\section{Journal of Psychology}

(Aus dem Psycholog. Institut, Tukyo Kaiserl. Universität)

Über die Blickrichtung und die Mondtäuschung

(Referat)

von

S. Morinaga

Die vorliegende Arbeit handelt sich um die folgenden noch nicht ganz gelösenen Fragen:

(1) Wie verändern die Sehgrösse und die Sehentfernungen mit den Blickrichtungen?

(2) Wie verhalten sich die Sehgrösse und die Sehentfernungen in verschiedenen Blickrichtungen?

(3) Was soll man unter den Blickrichtungen verstehen, die die Sehgrösse oder die Sehentfernungen bedingen?

Methode: Es ist die Aufgabe, die Grösse oder die Entfernungen von der Reizobjekte in zwei verschiedenen Blickrichtungen bei verschiedenen Körperlagen zu vergleichen. Reizobjekt: weisse Kreise aus dem Karton, die von $3.6 \mathrm{~cm}$. bis zu $6.8 \mathrm{~cm}$. Diameter haben. Körperlage: aufrechtstehen, $45^{\circ}$ schräge Rückenlage und horizontal auf dem Rücken liegen. Blickrichtungen: $90^{\circ}, 60^{\circ}, 40^{\circ}, 20^{\circ}$ aufwärts, $20^{\circ}, 40^{\circ}, 60^{\circ}$ abwärts, und gerade horizontal. Beobachtungsweise: 1) nur mit den Augen auf und ab blicken, 2) nur mit dem bewegten Kopf oben und unten sehen, 3) nur mit dem bewegten Oberkörper. Entfernungen der Objekte: $1 \mathrm{~m}$.

Ergebnisse: 1) Wenn die Körper aufrechtsteht, erscheint der Kreis bei gehobener oder gesenkter Blickrichtung kleiner als bei gerader. Aber in anderen Körperlagen ist es verschieden. In der Körperlage $45^{\circ}$ wird die Schätzung etwas unregelmässig. In der Horizontallage erscheint der Kreis bei 
gehobener Blickrichtung $90^{\circ}$-(objektiv horizontal) grösser als bei gerader (objektiv vertikal oben). Also ist die Wahrnehmung von Grössen mehr von den objektiven Raumrichtungen als den Blickrichtungen eindeutig bestimmt.

In bezug auf die Wahrnehmung von Entfernung, werden die Kreise bei gelobenen Blickrichtungen immer entfernter gesehen als bei gesenkten. In vielen Körperlagen sind die Richtungen der Objekte nach dem Körper von Bedeutung, jedoch in der horizontalen schätzen einige Vpn. die Richtung $90^{\circ}$ oben (objektiv horizontal) näher als die gerade (objektiv vertikal oben). In letzten Fall gilt das von der Grössenwahrnehmung erwähnte.

(2) In verschiedenen Blickrichtungen sind auch die Sehgrösse und die Sehentfernung abhängig von einander, abẻr die erwähnte Phänomene sind nicht allein zu einem von beiden zu zuschreiben.

(3) Aus den Ergebmissen werden wir zu einer Folgerung gelangen. Die Richtung, die die Grösse bedingt derart, dass die Objekte bei horizontaler grösser als bei vertikal oberer erscheinen, ist nicht die im Sinne der Blickrichtung, sondern der objektiven Richtung. Das Richten der Augen oder des Kopfes nach oben ist nur ein, aber gewöhnlich und häufigst gebrauchtes Mittel, objektiven oberen Richtungen zu sehen. Auf anderen Weise werden die Objekte bei oberen Richtungen kleiner gesehen als bei horizontaler. Die Blickrichtung nimmt als solches Mittel an der Grössenwahrnehmung teil, nur mit ihrer einigermassen selbständigen Wirkung.

Auch ist Mondtäuschung vielleicht mehr von der objektiven Richtung als von der Blickrichtung bedingt. 